\title{
Cerium Oxide Nanoparticles: A New Therapeutic Tool in Liver Diseases
}

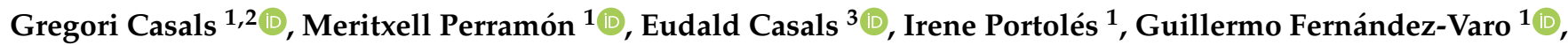 \\ Manuel Morales-Ruiz ${ }^{1,2,4}$, Victor Puntes ${ }^{5,6,7}$ and Wladimiro Jiménez ${ }^{1,4, *(1)}$
}

1 Service of Biochemistry and Molecular Genetics, Hospital Clinic Universitari, Centro de Investigación Biomédica en Red de Enfermedades Hepáticas y Digestivas (CIBERehd), Institut d'Investigacions, Biomèdiques August Pi i Sunyer (IDIBAPS), 08905 Barcelona, Spain; casals@clinic.cat (G.C.); mperramon@clinic.cat (M.P.); iportoles@clinic.cat (I.P.); guillermo.fernandez@ciberehd.org (G.F.-V.); morales@clinic.cat (M.M.-R.)

2 Comission for the Biochemical Assessment of Hepatic Disease-SEQCML, 08036 Barcelona, Spain

3 School of Biotechnology and Health Sciences, Wuyi University, Jiangmen 529020, China; wyuchemecm@126.com

4 Departament of Biomedicine, University of Barcelona, 08036 Barcelona, Spain

5 Vall d'Hebron Research Institute (VHIR), 08035 Barcelona, Spain; victor.puntes@icn2.cat

6 Institut Català de Nanociència i Nanotecnologia (ICN2), CSIC, The Barcelona Institute of Science and Technology (BIST), Campus UAB, Bellaterra, 08193 Barcelona, Spain

7 Institució Catalana de Recerca i Estudis Avançats (ICREA), 08010 Barcelona, Spain

* Correspondence: wjimenez@clinic.cat; Tel.: +34-93-2275400 (ext. 3091)

Citation: Casals, G.; Perramón, M.; Casals, E.; Portolés, I.;

Fernández-Varo, G.; Morales-Ruiz, M.; Puntes, V.; Jiménez, W. Cerium Oxide Nanoparticles: A New Therapeutic Tool in Liver Diseases. Antioxidants 2021, 10, 660. https:// doi.org/10.3390/antiox10050660

Academic Editors: Teresa Carbonell Camós and Joan Roselló-Catafau

Received: 26 March 2021

Accepted: 19 April 2021

Published: 24 April 2021

Publisher's Note: MDPI stays neutral with regard to jurisdictional claims in published maps and institutional affiliations.

Copyright: () 2021 by the authors. Licensee MDPI, Basel, Switzerland. This article is an open access article distributed under the terms and conditions of the Creative Commons Attribution (CC BY) license (https:// creativecommons.org/licenses/by/ $4.0 /)$.
Abstract: Oxidative stress induced by the overproduction of free radicals or reactive oxygen species (ROS) has been considered as a key pathogenic mechanism contributing to the initiation and progression of injury in liver diseases. Consequently, during the last few years antioxidant substances, such as superoxide dismutase (SOD), resveratrol, colchicine, eugenol, and vitamins $E$ and $C$ have received increasing interest as potential therapeutic agents in chronic liver diseases. These substances have demonstrated their efficacy in equilibrating hepatic ROS metabolism and thereby improving liver functionality. However, many of these agents have not successfully passed the scrutiny of clinical trials for the prevention and treatment of various diseases, mainly due to their unspecificity and consequent uncontrolled side effects, since a minimal level of ROS is needed for normal functioning. Recently, cerium oxide nanoparticles $\left(\mathrm{CeO}_{2} \mathrm{NPs}\right)$ have emerged as a new powerful antioxidant agent with therapeutic properties in experimental liver disease. $\mathrm{CeO}_{2} \mathrm{NPs}$ have been reported to act as a ROS and reactive nitrogen species (RNS) scavenger and to have multi-enzyme mimetic activity, including SOD activity (deprotionation of superoxide anion into oxygen and hydrogen peroxide), catalase activity (conversion of hydrogen peroxide into oxygen and water), and peroxidase activity (reducing hydrogen peroxide into hydroxyl radicals). Consequently, the beneficial effects of $\mathrm{CeO}_{2} \mathrm{NPs}$ treatment have been reported in many different medical fields other than hepatology, including neurology, ophthalmology, cardiology, and oncology. Unlike other antioxidants, $\mathrm{CeO}_{2} \mathrm{NPs}$ are only active at pathogenic levels of ROS, being inert and innocuous in healthy cells. In the current article, we review the potential of $\mathrm{CeO}_{2} \mathrm{NPs}$ in several experimental models of liver disease and their safety as a therapeutic agent in humans as well.

Keywords: nanoceria; liver steatosis; liver regeneration; hepatocellular carcinoma

\section{Antioxidant Properties of $\mathrm{CeO}_{2} \mathrm{NPs}$}

The therapeutic ability of cerium oxide nanoparticles $\left(\mathrm{CeO}_{2} \mathrm{NPs}\right)$ to act as a redox buffer and balance redox homeostasis in conditions in which increased oxidative stress plays a pathogenic role makes them one of the most promising medical nanoparticles to address the different conditions related to chronic inflammation and oxidative stress. 
$\mathrm{CeO}_{2} \mathrm{NPs}$ are considered a multi-enzymatic nanozyme, since they can participate in numerous metabolic reactions mimicking the activity of endogenous enzymes. The catalytic capacities and other industrial activities of $\mathrm{CeO}_{2}$ have been known and applied for more than a century [1]. However, their powerful medical potential was not recognized until recently. The first report was from Beverly Rzigalinski and co-workers [2], who, with their "somewhat serendipitous discovery", showed that $\mathrm{CeO}_{2} \mathrm{NPs}$ prolonged the lifespan of brain cell cultures for periods of up to 6-8 months [3,4]. In their works, $\mathrm{CeO}_{2} \mathrm{NPs}$ were intended to be used as a drug delivery vehicle. Unexpectedly, they realized that brain cells incubated with $\mathrm{CeO}_{2} \mathrm{NPs}$ were still alive and actively signaling "as robustly as freshly prepared cultures" after months in the incubator [3]. Afterwards, they started a new set of experiments to finally describe for the first time $\mathrm{CeO}_{2} \mathrm{NPs}$ of less than $20 \mathrm{~nm}$ in size prolonging the life of mixed brain cell cultures and neurons within these cultures for periods of up to 6-8 months. A patent was presented [5] and three seminal abstracts were made public in 2003 [6-8].

From this point on, the interest in $\mathrm{CeO}_{2} \mathrm{NPs}$ and their catalytic properties against the accumulation of free radicals rapidly grew and expanded to other medical areas. In 2005, the first report of $\mathrm{CeO}_{2} \mathrm{NP}$ protection against $\mathrm{b}$ radiation-induced damage appeared. In the work of Tarnuzzer et al. [9], CRL8798 cells (immortalized normal human breast epithelial cell line) and MCF-7 (breast carcinoma cell line) were exposed to radiation and further treated with $\mathrm{CeO}_{2} \mathrm{NPs}$. The results showed that $\mathrm{CeO}_{2} \mathrm{NPs}$ conferred radioprotection to the normal human breast line but not to the tumoral line. In 2006, the first report on the use of $\mathrm{CeO}_{2}$ in neurology was published. Schubert et al. [10] found that $\mathrm{CeO}_{2} \mathrm{NPs}$ are neuroprotective and can limit the amount of ROS needed to decrease the viability of nerve cells using a HT22 hippocampal nerve cell line. The following year, Das et al. [11] showed similar neuroprotective effects using adult rat spinal cord neurons. Additionally, in 2006 the use of $\mathrm{CeO}_{2}$ in ophthalmology was reported for the first time. Chen et al. [12] showed how $\mathrm{CeO}_{2} \mathrm{NPs}$ can prevent retinal degeneration induced by intracellular peroxides, thus preserving retinal morphology and preventing loss of retinal function. These authors performed both in vitro and in vivo experiments. Retinal protection was shown for primary cells dissociated from rat retina incubated with $\mathrm{CeO}_{2} \mathrm{NPs}$ and through the injection of a suspension of $\mathrm{CeO}_{2} \mathrm{NPs}$ into the vitreous of both eyes in an albino rat light-damage model. The following year, the first report of the cardioprotective effects of $\mathrm{CeO}_{2} \mathrm{NPs}$ appeared. Niu et al. [13] showed that i.v.-injected $\mathrm{CeO}_{2} \mathrm{NPs}$ in a transgenic murine model of cardiomyopathy reduced myocardial oxidative stress and endoplasmic reticulum stress and suppressed the inflammatory process. The first report we have found on the use of $\mathrm{CeO}_{2} \mathrm{NPs}$ in the context of liver disease is the 2013 work of Hirst et al. [14]. These authors showed that $\mathrm{CeO}_{2} \mathrm{NPs}$, administered both i.v. and intraperitoneally (i.p.) to mice with carbon tetrachloride $\left(\mathrm{CCl}_{4}\right)$-induced liver toxicity, showed similar and more sustained effects than mice treated with $\mathrm{N}$-acetyl cysteine (NAC), a common therapeutic to reduce oxidative stress. Nowadays, many reports and studies are constantly appearing with very promising results [15].

The mechanisms responsible for these therapeutic activities are related to the $\mathrm{CeO}_{2} \mathrm{NP}$ dual status of oxidation. In nature, cerium oxide can form two main crystal structures, cerium (IV) oxide $\left(\mathrm{CeO}_{2}\right)$ and cerium (III) oxide $\left(\mathrm{Ce}_{2} \mathrm{O}_{3}\right)$, with $\mathrm{CeO}_{2}$ being the most stable phase at room temperature and under atmospheric conditions. When the size of the particle is reduced to the nanometric regime, a large amount of surface defects appear in the $\mathrm{CeO}_{2}$ crystal structure, primarily caused by the reversible removal of oxygen atoms from the surface. Electrons left behind by released oxygen localize on empty $f$ states of cerium ions, being reduced from $\mathrm{Ce}^{4+}$ to $\mathrm{Ce}^{3+}[16]$. Hence, $\mathrm{CeO}_{2} \mathrm{NPs}$ have two oxidation states, $\mathrm{Ce}^{3+}$ and $\mathrm{Ce}^{4+}$, which confer upon them the characteristic of generally two auto regenerative redox cycles between $\mathrm{Ce}^{3+}$ and $\mathrm{Ce}^{4+}$, which are associated with the release of oxygen at the surface. This translates into powerful antioxidant properties, since the lack of oxygen enables the appearance of reactive sites on the surface of the nanoparticles, and these reactive sites are able to scavenge free radicals [14]. 
It is therefore the ability of $\mathrm{CeO}_{2} \mathrm{NPs}$ to change their oxidation state depending on the surrounding environment and thereby be involved in oxidation reactions that makes $\mathrm{CeO}_{2} \mathrm{NPs}$ such a promising material for use in biomedicine. The key factor is their ability to participate in biochemical redox processes, especially in the modulation of oxidative stress in living organisms. Briefly, oxidative stress occurs when cells are no longer able to control the physiological levels of free radicals (molecules with unpaired electrons in the valence shell and that are therefore highly chemically reactive). The normal metabolism of the cell produces free radicals, principally reactive oxygen species (ROS), and control their levels. Under many conditions of stress (e.g., exposure to UV radiation, diet), the accumulation of ROS overwhelms defense mechanisms, resulting in damaged cellular structures. Furthermore, the network of endogenous antioxidants (superoxide dismutase [SOD], catalase, peroxidase, glutathione (GSH), etc.) is complex in itself and is interrelated [17] (for instance, SOD produces $\mathrm{H}_{2} \mathrm{O}_{2}$ as a product of the degradation of $\mathrm{O}_{2}$, etc.). The accumulation of ROS is known to lead to DNA damage (by the oxidation of nucleotides and induction of mutagenesis), protein degradation, and lipid peroxidation, which are reactions that ultimately lead to inflammatory processes [18]. In turn, inflammation itself triggers a higher ROS production by the cells of the immune system as a mechanism of innate defense to form a less friendly environment for pathogens [19]. Therefore, an excess of ROS induces inflammation. However, the reverse sequence of these events is also true; inflammation induces ROS to alter immune cell phenotypes and activate them in a type of positive reciprocal feedback loop [20-24].

To decrease the levels of ROS and stop this vicious ROS inflammation cycle, the oxygen electronic state of these ROS is changed and they are converted into benign molecules such as $\mathrm{O}_{2}$ and $\mathrm{H}_{2} \mathrm{O}$ through reactions catalyzed by different endogenous enzymes. The redox activity of $\mathrm{CeO}_{2} \mathrm{NPs}$ is similar to that of biological antioxidants, and during the last two decades the following have been described for $\mathrm{CeO}_{2} \mathrm{NPs}$ : SOD activity $[25,26]$ (the conversion of superoxide anion into hydrogen peroxide and finally oxygen), catalase activity $[27,28]$ (hydrogen peroxide into oxygen and water), and peroxidase activity [29] (hydrogen peroxide into hydroxyl radicals), as well as nitric oxide (NO) scavenging ability [30], among others. Here, it is worth noting that thanks to this auto-regenerative redox cycle, $\mathrm{CeO}_{2} \mathrm{NPs}$ can participate in these enzymatic reactions by catalytically degrading the excess of different ROS-i.e., without being totally consumed in the reaction and enabling longer and sustained activity compared with the shorter half-life of classic (small molecule) antioxidants. In addition, when doing this, due to their peculiar electronic structure, $\mathrm{CeO}_{2} \mathrm{NPs}$ act as a buffer, balancing redox homeostasis. This means that their biological activity is only carried out in the case of ROS overproduction [31] and they become a rather inert material in healthy physiological conditions, slowly dissolving into innocuous cerium ions which are finally expulsed via the urinary track or the hepatic route $[32,33]$. Thus, $\mathrm{CeO}_{2} \mathrm{NPs}$ are considered one of the major players in what has recently been called "nanocatalytic medicine" [34], or "ROS-based nanomedicine" [35], understood as the use of nanozymes [36,37] and antioxidant nanomaterials [38] (and also photocatalysts and electrocatalysts) to initiate catalytic (enzymatic) reactions and modulate biological microenvironments to generate therapeutic effects.

Thus, over the last few years the many advantages of $\mathrm{CeO}_{2} \mathrm{NPs}$ over classic (small molecule) antioxidants have been described. Classic antioxidants, such as SOD, ascorbic acid, resveratrol, colchicine, eugenol, and vitamin E, have shown only limited success in clinical applications $[1,39,40]$. This has been called the antioxidant paradox, since they were thought to have a higher bioactivity against oxidative stress and ageing. The shortcomings of these antioxidants accounting for the unsuccessful clinical trials are their limited activity, since they are metabolized-i.e., after the reaction they become inactivated (hence, they are considered to have a short half-life)—and the fact that they often scavenge only one free radical [23]. This limited activity is also related to the reaction environment. For instance, while vitamin $C$ acts in intracellular and extracellular environments, vitamin $\mathrm{E}$ acts in the membrane. In addition, to date the state of the design of efficient small-molecule 
antioxidants with targeted activity is still somewhat lacking. $\mathrm{CeO}_{2}$, in its nanoparticle form, can overcome these drawbacks and may provide to the field of medicine an effective longlasting antioxidant for the treatment of a broad spectrum of diseases associated with free radical production, especially in the cases of autoimmune diseases, chronic inflammation, organ rejection, pathogenic immune response, and conditions related to aging. First, because NPs can be easily functionalized by targeting peptides or molecules, they can thus be designed to be used for local targeting and delivery to specific cellular types or damaged tissues. In addition, as mentioned previously, $\mathrm{CeO}_{2} \mathrm{NPs}$ scavenge different $\mathrm{ROS}$ without being consumed during the reaction. Thus, even at low doses, they can be more effective and have long-lasting activity in a multiplicity of cross reactions between ROS and inflammation at any level, which will ultimately allow disconnecting these two events [15].

\section{Liver Regeneration}

The liver has the capacity to regenerate owing to the ability of adult hepatocytes to proliferate upon toxic injury and infection. Liver regeneration occurs similarly in humans and rodents. In 1931, Higgins and Anderson established the first experimental model of liver regeneration in rodents named partial hepatectomy (PHx). By means of this procedure and benefiting from the multilobular structure of rodent liver, it is possible to remove two thirds of the liver by the resection of the median lobe and the left lateral lobe [41]. Thenceforth, this model has been widely used to study liver regeneration, liver function, and response to trauma and stress.

Liver regeneration is a compensatory process driven to restore liver function. After $\mathrm{PHx}$, the remnant liver enlarges until the original liver mass is reestablished because of the cellular hyperplasia of mature liver cells. Typically, 7 days after PHx the liver restores the majority of its mass and after 3 weeks complete restoration is accomplished [42,43].

The process of liver regeneration after PHx is complex and implicates the coordination of many initiation and termination pathways. Although hepatocytes are the major contributors to liver regeneration, it is not solely these cells that participate in this process; cholangiocytes, hepatic stellate cells (HSCs), Kupffer cells, and liver sinusoidal endothelial cells are also involved.

Liver regeneration can be explained by three different phases. The early activation phase triggers a signaling cascade of cytokines that activate the transcription factors needed for liver regeneration. During the second phase, DNA synthesis and cell proliferation take place due to mitosis. In the termination phase, the original liver mass is restored by hyperplasia and liver regeneration stops [44].

Early activation phase: In this initial phase, different cytokines and growth factors are responsible for the transition between quiescence and mitosis, allowing hepatocytes to enter in the G1 phase of the cell cycle. Kupffer cells rapidly regulate the early stage of regeneration by secreting interleukin 6 (IL-6) and tumor necrosis factor alpha (TNF $\alpha$ ) [42]. IL-6 is essential for the proper functioning of the liver, since it participates in acute phase response and mitosis. IL-6 is a key mediator of gene expression activation during liver regeneration, triggering the expression of $36 \%$ of genes that activate in the early phase of this process. Hepatic macrophages and hepatocytes produce IL-6 rapidly after PHx. The linkage of IL-6 with its receptor (IL-6R) triggers a signaling cascade that induces the activation of transcription of certain genes via STAT3 phosphorylation and activates mitogen-activated protein kinase (MAPK), which initiates mitosis, via gp130 phosphorylation [42,43]. After PHx, Kupffer cells rapidly express TNF $\alpha$, which up-regulates the nuclear factor kappa-light-chain enhancer of activated $\beta$ cells (NF- $\kappa B$ ) expression through the activation of IL- 6 transcription. TNF $\alpha$ can act as both a protector and promoter of liver injury $[42,45,46]$. Nonetheless, NF- $\mathrm{kB}$ signaling mediated by TNF $\alpha$ is anti-apoptotic; mice deficient in TNF receptor 1 or 2 presented a delayed regeneration and lower activation of NF- $\mathrm{B}[47,48]$. In this phase, the action of growth factors that stimulate cellular replication is also fundamental. As such, hepatocyte growth factor (HGF) is implicated in promoting hepatocyte proliferation and inducing DNA synthesis. Immediately after 
PHx, the activation of the urokinase-type plasminogen activator (uPA) occurs, allowing the conversion of plasminogen into plasmin, and, consequently, activating metalloproteinases [49]. Thereafter, there is a remodeling of some components of the extracellular matrix (ECM). When the vascular endothelial growth factor (VEGF) binds to endothelial cells, HSCs release the inactive HGF precursor [42]. uPA mediates the activation of the HGF precursor by the cleavage and release of HGF. HGF binds to the Met receptor on hepatocytes, activating the PI3K, AKT, and S6 kinase signal-transduction pathways (TOR). Upon HGF signaling, transforming growth factor alpha (TGF $\alpha$ ) is released, triggering a cascade of different downstream signals that together activate TOR. Upon uPA blockade, HGF action is delayed, hindering liver regeneration [50]. In brief, HGF and TGF $\alpha$ are the main regulators of the mitogenic response of the liver. When liver regeneration terminates, the normal state of ECM is reestablished.

Proliferation phase: in the normal liver, functional hepatocytes are found in a quiescent state, maintaining their ability to divide in response to damage or infection. After PHx, hepatocytes are the first cells to undergo cell division; they also act as activators of proliferation of other hepatic cell types by producing mitogenic signals. In mice, the peak of hepatocyte proliferation occurs at between 36 and $48 \mathrm{~h}$, with the highest DNA synthesis being found at $40 \mathrm{~h}$; in rats, the peak is observed at $24 \mathrm{~h}$ [42,51,52].

Termination phase: The mechanisms leading to the termination of regeneration have still not been completely elucidated. The speed of the hepatic regenerative process is determined by the mass amount of the excised liver, which is proportionally correlated. At between $40 \%$ and $70 \%$ liver resection, the process evolves at an optimal speed. If only 30\% or less of the liver is removed, the speed notably decreases and the growth of the remnant liver slows down, even if the mass is ultimately restored. The resection of more than the $85 \%$ of the liver volume is associated with mortality and poor regeneration. However, when the original liver mass is restored, liver regeneration completely stops [53]. Cytokines and growth factors are also implicated in the termination phase of this process, regulating liver size. Through the action of Janus kinases (JAK), the suppressor of cytokine signaling3 (SOCS-3) impedes the phosphorylation of STAT-3, preventing and blocking cytokine signaling. IL-6 is the main regulator of the mRNA expression levels of SOCS-3. After PHx, SOCS-3 is up-regulated, leading to the down-regulation of STAT-3, and, consequently, down-regulating IL-6 in a negative feedback manner [42,54]. The duality of IL-6 acting as a proliferative and apoptotic agent might explain why IL-6 over-expression impedes cell growth, hindering liver regeneration [55]. TGF $\beta$ is the most well-known anti-proliferative factor in hepatocytes. HSC produces TGF $\beta$ and is over-expressed during liver regeneration. However, it has been described that hepatocytes become resistant to TGF $\beta$. Within $48 \mathrm{~h}$ after PHx, hepatocytes decrease the expression of TGF $\beta$ receptors and are then able to proliferate during regeneration, despite the high levels of TGF $\beta[51,56]$.

Smad proteins are intracellular effectors of TGF $\beta$ signaling. These proteins become active through interaction with different receptors, consequently translocating into the cell nuclei where they activate gene transcription. Smad proteins are slightly activated in quiescent hepatocytes, and their activation increases in liver regeneration. During regeneration, the expression of the inhibitors of the TGF $\beta /$ Smad pathway, SnoN and Ski, increases. These inhibitors impede transcription and can favor cellular resistance to TGF $\beta$ through their union to SMAD proteins [57].

\section{Cerium Oxide Nanoparticles as a Driver for Liver Regeneration}

To maintain optimal physiological functions and structural integrity, it is essential to ensure redox homeostasis. A proper balance between oxidants and antioxidants is obtained by controlling the production of ROS and RNS. ROS are oxygen free radicals, such as superoxide, with the addition of non-radicals, such as hydrogen peroxide, which are generated during the metabolism process of oxygen. RNS, such as nitrogen dioxide or NO radicals, are derived forms of $\mathrm{NO}$ and superoxide that arise from the action of 
inducible nitric oxide synthase (iNOS) and nicotinamide adenine dinucleotide phosphate (NADPH) [58,59].

Under physiological conditions, the oxidation of molecules resulting from the breakage of the DNA strand induced by ROS/RNS is normally held at bay, since the cellular production of anti-oxidants acts as a barrier defense. Amongst them, we find enzymatic anti-oxidants such as SOD, catalase, and glutathione peroxidase, as well as non-enzymatic anti-oxidants, such as vitamin-E, GSH, beta-carotene, tocopherol, and ascorbate [60-62].

ROS production is a natural process derived from the aerobic metabolic pathways, and under physiological conditions these molecules exert beneficial roles. For instance, ROS serve as a defense against microorganisms; they modulate gene expression in response to growth factors, hormones, cytokines, and extracellular ATP [60,63]. However, an imbalance in the production or elimination of ROS or a decreased availability of antioxidants leads to the commonly known state of oxidative stress. In general, a sustained situation of oxidative stress may induce cell death, causing tissue damage.

Due to its highly metabolic functions, the liver is very sensitive to redox imbalances. Proteins, lipids, and DNA in hepatocytes are the molecules that are mainly affected by oxidative stress. Cysteine, tyrosine, tryptophan, and histidine are the main amino acids that are compromised by high levels of ROS [60]. Proteins rich in these amino acids are direct targets of ROS, becoming modified and consequently proteolyzed after their action.

Imbalances in ROS levels that lead to oxidative stress are crucial in liver diseases and chronic liver injury. Oxidative stress causes hepatic damage by altering proteins, lipids, and DNA, as well as modulating pathways involved in gene transcription, protein expression, cell apoptosis, and HSC activation. In the pathological setting of the liver, oxidative stress exacerbates fibrosis by activating HSCs, steatosis by causing lipid peroxidation, and inflammation that can lead to chronic hepatitis by triggering mitochondrial dysfunction and immune cell infiltration. All these pathological conditions can contribute to the development of hepatocellular carcinoma (HCC) [59]. Despite ROS playing an important role in liver disease, a therapeutic approach directly targeting ROS is still not available in the clinical setting.

In recent times, $\mathrm{CeO}_{2} \mathrm{NPs}$ have been tested for biomedical purposes, since their ability to scavenge free radicals may serve as a new therapeutic tool to treat oxidative stressrelated diseases. In this regard, the beneficial effect of $\mathrm{CeO}_{2} \mathrm{NPs}$ in liver pathologies has recently been described in several studies. However, despite the increasing interest in the hepatoprotective properties of nanoceria in liver diseases, little is known about their role in liver regeneration. As mentioned above, during liver regeneration it is essential to maintain the proliferative state until the original liver mass is restored. However, in many liver diseases the accumulation of ROS may impede optimal regeneration due to the induction of apoptosis because of lipid peroxidation, subsequently preventing the resolution of tissue damage. ROS act as mediators in the regulation of different growth factors, transcription factors, and cell cycle proteins such as $\beta$-catenin, cyclin D, p53, and NF-E2-related factor 2 (Nrf2) [64-68]. All these proteins are essential for the regenerative process, and improper regulation results in detrimental effects on liver regeneration.

The transcription factor Nrf2 is a pivotal agent in the protection against oxidative stress. Nrf2 is involved in the regulation of the expression of antioxidants, such as glutathione-Stransferase (GST), glutamate-cysteine ligase catalytic subunit (GCLC), and NADPH quinine oxidoreductase 1 (NQO1) [69]. Nrf2 binds to a specific site in the promoter region of its target genes named antioxidant response element (ARE) [70]. Beyer et al. further described the role of Nrf2 in liver regeneration in relation to ROS production. In their Nrf2 knockout $(\mathrm{KO})$ mice, they studied liver regeneration upon PHx and found a significant delay in regeneration in the absence of Nrf2 as well as enhanced hepatocyte apoptosis. In this study, they also observed reduced GST activity in the KO mice and increased oxidative stress [71]. Later on, the role of Nrf2 as an activator of augmenter of liver regeneration (ALR) was described [72]. Therefore, it was concluded that Nrf2 is a key regulator of the redox state. From these results, the relationship between the redox state and liver regeneration is 
evident. Francés et al. analyzed the effects of free radical scavengers in the early stages of PHx. It is known that diabetes mellitus induces lipid peroxidation through the generation of hydroxyl radicals. For this reason, they used a streptomycin-induced diabetes model in rats and subjected them to treatment with desferoxamine (DES) or tempol (TEM), two known free radical scavengers, and studied their effects over $24 \mathrm{~h}$ after hepatectomy. Their results show a decreased ROS production and the activation of caspase- 3 upon DES and TEM treatment, thereby preventing apoptosis and ameliorating liver regeneration in a diabetic setting [73].

It was not until 2019 that Cordoba-Jover et al. [68] first studied the effects of using CeO2NPs on liver regeneration using the experimental model of PHx and acetaminophen (APAP)-induced liver injury in rats. In the context of PHx, rats were administered with $\mathrm{CeO}_{2} \mathrm{NPs}$ or vehicle two weeks before $\mathrm{PHx}$ and sacrificed 6 days after surgery. Rats treated with $\mathrm{CeO}_{2} \mathrm{NPs}$ exhibited significantly increased liver regeneration and hepatocyte proliferation compared to control groups [68]. In the context of APAP-induced liver injury, the therapeutic effect of $\mathrm{CeO}_{2} \mathrm{NPs}$ was compared with NAC, the clinical gold-standard treatment. $\mathrm{CeO}_{2} \mathrm{NPs}$ and NAC treatment decreased early liver damage in hepatic tissue after APAP overdose. However, only the effect of CeO2NPs was associated with a significant increment in hepatocellular proliferation. In addition, treatment with $\mathrm{CeO}_{2} \mathrm{NPs}$ increases transcription factor NF-kB activation by decreasing the IKB $\alpha$ expression (Figure 1). The link between $\mathrm{CeO}_{2} \mathrm{NP}$ activity and the downregulation of IKB $\alpha$ seems to lie in the inhibition of the IkB kinase (IKK) complex by high levels of oxidative stress. In the absence of oxidative stress, IKK phosphorylates IkB proteins [74], leading to protein ubiquitination, which is followed by the proteasome-mediated degradation of IkB proteins.

a)

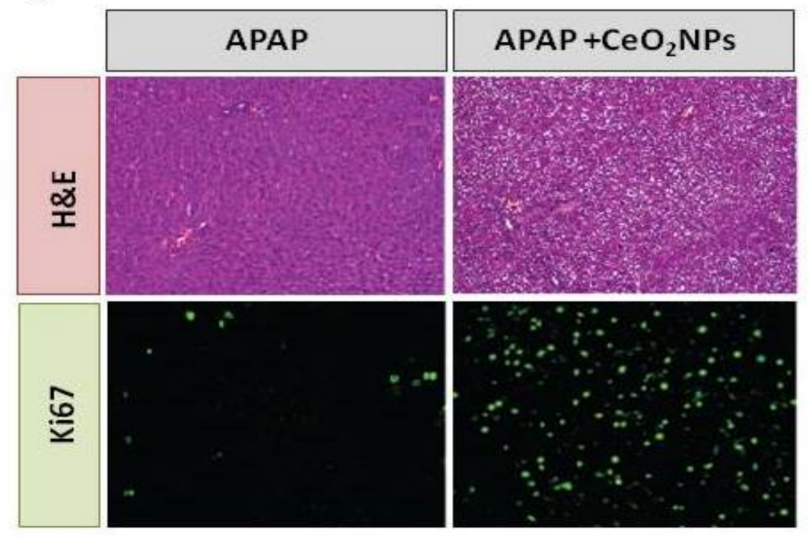

b)

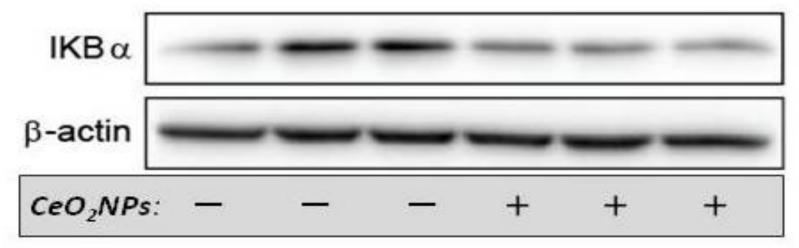

c)

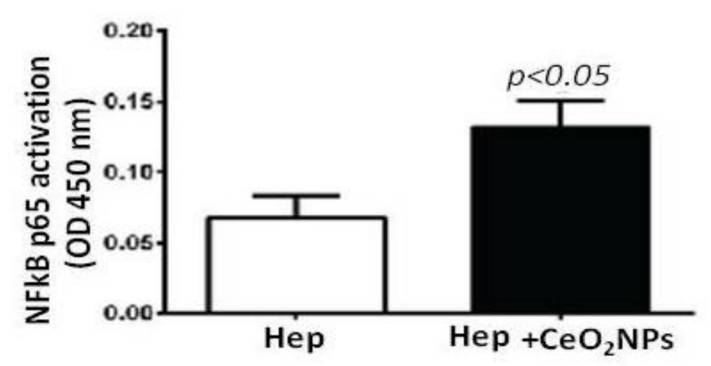

Figure 1. (a) Rats received vehicle or $1 \mathrm{~g} / \mathrm{kg}$ acetaminophen (APAP) after $\mathrm{CeO}_{2} \mathrm{NP}$ treatment. The top panels show hematoxylin-eosin stained liver sections. The bottom panels show immunostaining for Ki-67 (green) used as a marker of hepatocellular proliferation. Magnification: $100 \times$. (b) Western blot for IK $\beta B \alpha$ expression in the HepG2cell line treated with vehicle or $\mathrm{CeO}_{2} \mathrm{NP}$. (c) Transcription factor immunosorbent assay for p65 activity in the cell line HepG2 treated with vehicle or $\mathrm{CeO}_{2} \mathrm{NP}$ (adapted from reference [68]). 
These results agree with studies that showed that NF-kB activity is needed for liver regeneration and that impaired NF-kB activation is associated with embryonic lethality and liver degeneration. This study reflects the beneficial properties of $\mathrm{CeO}_{2} \mathrm{NPs}$ and the positive impact on stimulating liver regeneration.

\section{Fatty Liver Disease}

The definitions of non-alcoholic fatty liver disease (NAFLD) have been based on the presence of fat accumulation (steatosis) in hepatocytes in the absence of significant alcohol consumption or other known causes of liver disease [75,76]. A more recent definition proposed by a panel of international experts considers metabolic dysfunction-associated fatty liver disease (MAFLD) to be a more appropriate term for this liver disease, which is highly associated with known metabolic dysfunctions [77]. Regardless of alcohol consumption or other concomitant liver diseases, the new diagnosis of MAFLD is based on the evidence of hepatic steatosis in addition to one of the following three criteria-namely, (1) overweight/obesity, (2) type 2 diabetes mellitus, or (3) two additional metabolic risk abnormalities [77].

MAFLD is currently the most common cause of liver disease. It already affects one quarter of the adult population [78] and is a major health and economic burden [79]. It is associated with increased cardiovascular and liver-related morbidity and mortality and, at present, there is a lack of approved pharmacotherapy [77]. Therefore, the identification of new therapeutic strategies is urgent in order to reduce the increase in chronic liver disease that can be derived from the high prevalence of MAFLD among the population.

\subsection{Lipid Peroxidation}

Two main histological categories may be considered in MAFLD: simple fatty liver, with a favorable clinical outcome, and non-alcoholic steatohepatitis (NASH), characterized by inflammation in addition to the fat infiltration of the liver, and at higher risk of developing fibrosis, cirrhosis, liver failure, and hepatocarcinoma. Fat accumulation in the hepatocytes is the result of an increased inflow of free fatty acids, de novo lipogenesis, or impaired fat oxidation. Elevated hepatic oxidative stress and lipid peroxidation play roles in the pathogenesis of MAFLD and NASH. Increased ROS generation triggers lipid peroxidation, the release of inflammatory cytokines, and cell death. Both biologically active lipid peroxidation products and cytokines act together to trigger the diverse hepatic lesions of NASH by inducing hepatic inflammation and fibrosis, which eventually lead to end-stage liver disease. Patients with NASH display both an increase in ROS and nitrogen species production and a lack of endogenous antioxidant defenses [78]. ROS can attack polyunsaturated fatty acids and initiate lipid peroxidation within the cell, which results in the formation of aldehyde by-products such as malondialdehyde (MDA) and 4hydroxynonenal. These by-products, with longer half-lives than ROS and easily diffusible, amplify the effects of oxidative stress [79].

MDA, which results from the lipid peroxidation of polyunsaturated fatty acids, is the major lipid oxidation product in biological samples. Therefore, MDA and related thiobarbituric acid reactive substances (TBARS) are widely used as markers of lipid peroxidation. At a dose of $50 \mu \mathrm{g} / \mathrm{mL}, \mathrm{CeO}_{2} \mathrm{NPs}(25 \mathrm{~nm})$ decreased cell viability and increased the production of ROS and MDA in HCC SMMC-7721 cells cultured in basal conditions [80]. This effect was not observed at a dose $<50 \mu \mathrm{g} / \mathrm{mL}$, suggesting that very high doses of $\mathrm{CeO}_{2} \mathrm{NPs}_{\text {may }}$ induce oxidative stress in control cells. In contrast, protective effects of $\mathrm{CeO}_{2} \mathrm{NPs}$ against lipid peroxidation have been found under different experimental conditions of liver disease. Thus, HepG2 cells incubated in high-glucose medium showed an increase in ROS formation, as well as TBARS levels that were remarkably reduced after treatment with $50 \mathrm{nM}$ $(8.5 \mu \mathrm{g} / \mathrm{mL})$ nanoceria [81]. In vivo evidence of a potential effect of $\mathrm{CeO}_{2} \mathrm{NPs}$ in reducing lipid peroxidation includes the study of Hirst et al. [14] in a BALB/c mice model of liver disease induced with $\mathrm{CCl}_{4}$. Treatment with $\mathrm{CeO}_{2} \mathrm{NPs}(4 \mathrm{~nm})$ reduced MDA in plasma after 2 weeks of $\mathrm{CCl}_{4}$ administration. In another study, the i.p. administration of $\mathrm{CeO}_{2} \mathrm{NPs}$ to 
mice with D-galactoseamine and lipopolysaccharide-induced hepatotoxicity resulted in decreased levels of TBARS in comparison with non-treated animals [82]. Additionally, a reduction in MDA levels was observed after the administration of $\mathrm{CeO}_{2} \mathrm{NPs}(25 \mathrm{~nm})$ to Sprague Dawley rats with hepatic toxicity induced by doxorubicin [83] and to Wistar rats with fatty liver induced by a methionine- and choline-deficient diet [84]. A decrease in lipid peroxidation was also observed in Wistar rats with monosodium glutamate-induced obesity when treated orally with $\mathrm{CeO}_{2} \mathrm{NPs}$ in two-week courses alternated with two-week breaks for 3 months. In comparison to non-treated rats, rats receiving $\mathrm{CeO}_{2} \mathrm{NPs}$ presented a reduced liver tissue content of diene conjugates, TBA-active products, and Schiff bases [85]. The oral administration of $\mathrm{CeO}_{2} \mathrm{NPs}(<25 \mathrm{~nm})$ also protected albino rats against hepatotoxicity induced by fipronil. The effects included reduction in the hepatic levels of MDA and nitric oxide, and also an improvement in the hepatic activities of glutathione peroxidase and superoxide dismutase [86].

\subsection{Liver Steatosis}

The effects of $\mathrm{CeO}_{2} \mathrm{NPs}$ on liver steatosis have also been evaluated. Kitchin et al. found significant effects on lipids in metabolomic studies evaluating the potential hepatotoxicity of $\mathrm{CeO}_{2} \mathrm{NPs}$ in human liver HepG2 cells [87]. Specifically, HepG2 cells were exposed for 3 days to two commercial $\mathrm{CeO}_{2}$ nanomaterials $(8$ and $58 \mathrm{~nm}$ ) at 3 or $30 \mu \mathrm{g} / \mathrm{mL}$. Significant increases in lipid metabolites after treatment with $\mathrm{CeO}_{2}$ nanopowders were observed and found to be almost exclusively related to the smaller size $8 \mathrm{~nm} \mathrm{CeO}_{2}$ nanomaterial. Thus, cells treated with $8 \mathrm{~nm} \mathrm{CeO} 2 \mathrm{NPs}$ at $3 \mu \mathrm{g} / \mathrm{mL}$ increased the levels of 11 of 24 fatty acids around 1.3-1.5 fold, and cells incubated with the same nanoparticles at the higher dose of $30 \mu \mathrm{g} / \mathrm{mL}$ increased the levels of 20 of 24 fatty acids around 1.5-2 fold. In contrast, the effects of $58 \mathrm{~nm} \mathrm{CeO} 2 \mathrm{NPs}$ on lipids were minimal and only an increase of one fatty acid (1.4-fold) was found at the higher incubation dose of $30 \mu \mathrm{g} / \mathrm{mL}$. In agreement with these results, fatty acid synthase (FASN) gene expression was upregulated (1.6 fold) only in HepG2 treated with $8 \mathrm{~nm}$ at the higher dose [88]. The same group further evaluated metabolomic effects on HepG2 cells after 3 days of exposure to $\mathrm{CeO}_{2} \mathrm{NPs}$ using different commercial $\mathrm{CeO}_{2}$ nanopowders and observed similar nanomaterial-induced elevations in fatty acids and monoacylglycerols [89]. In contrast, when HepG2 cells were exposed to oleic and palmitic acid to establish an in vitro model of hepatocellular steatosis, a significant reduction in the content of saturated fatty acids was observed in response to a treatment with colloidally stable (synthesized and stabilized with tetramethylammoniun hydroxide) $4 \mathrm{~nm} \mathrm{CeO} 2 \mathrm{NPS}(10 \mu \mathrm{g} / \mathrm{mL})$ for $24 \mathrm{~h}$. [90]. These contradictory results under normal and steatotic conditions may be related to the activity of $\mathrm{CeO}_{2} \mathrm{NPs}$ as nanozymes. Due to its particular electronic structure, $\mathrm{CeO}_{2}$ acts as a redox buffer-i.e., it balances redox homeostasis. Hence, its biological activity is mainly carried out in cases of an excess of ROS, while it is a rather inert material under physiological conditions [15]. In addition, the different doses employed and the aggregation of the commercial $\mathrm{CeO}_{2}$ nanopowders may have also an impact on the observed biological results. It is known that nanomaterials of dry origin are more unstable than synthesized colloidal stable NPs. In the mentioned works which used commercial $\mathrm{CeO}_{2}$ nanopowders [87-89], the particles needed to be resuspended in cell culture media prior to their incubation with cells. As expected, the characterization of the NPS in physiological media showed the presence of aggregates. Hence, it may be considered that these are different materials from those produced by wet chemistry routes in the laboratory, where the colloidally stable NPs are isolated and well dispersed in cell culture medium supplemented with serum. $\mathrm{CeO}_{2}$ colloids. This proneness of nanomaterials from dry origin to form aggregates in physiological media has been consistently associated with deleterious and toxic effects, as reported in a recent review [91].

There is some in vivo evidence in experimental models of liver disease reporting a reduction in liver steatosis with $\mathrm{CeO}_{2} \mathrm{NPs}$ treatment. Oró et al. [32] evaluated the systemic and hepatic effects of $\mathrm{CeO}_{2} \mathrm{NPs}(4 \mathrm{~nm})$ in rats with liver fibrosis induced by $\mathrm{CCl}_{4}$. Eight 
weeks after the i.v. administration of $\mathrm{CeO}_{2} \mathrm{NPs}(0.1 \mathrm{mg} / \mathrm{kg}$ bw, twice weekly for two weeks), nanoparticles were mainly located in the liver, and a morphometric measurement of fat revealed an almost $50 \%$ reduction in total steatosis, which was associated with an amelioration of systemic inflammatory biomarkers and improved portal pressure, among other protective effects. Carvajal et al. [85] evaluated the effect of $\mathrm{CeO}_{2} \mathrm{NPs}_{\mathrm{N}}(4 \mathrm{~nm})$ in a rat model of NASH induced by a 6-week methionine- and choline-deficient diet. Rats were treated with $\mathrm{CeO}_{2} \mathrm{NPs}$ (i.v. $0.1 \mathrm{mg} / \mathrm{kg}$ bw) twice weekly during weeks three and four of the diet. Treatment with $\mathrm{CeO}_{2} \mathrm{NPs}$ reduced the size and content of hepatocyte lipid droplets, as assessed by histological morphometric measurement. This was associated with a reduction in the hepatic content of triglyceride- and cholesterol ester-derived fatty acids, as assessed by mass spectrometry analysis. These antisteatoic effects on the liver were also accompanied by a reduction in the hepatic levels of MDA and different inflammatory factors. In addition, unpublished results from our laboratory suggest similar or greater antisteatotic effects of $\mathrm{CeO}_{2} \mathrm{NPs}$ in the liver of rats fed with a methionine- and cholinedeficient diet for 3 or 4 weeks, and, therefore, with a less established NASH, as observed by morphometric measurements of steatosis (Figure 2).

Although a methionine- and choline- deficient diet is a classical dietary model of NASH suitable for assessing the hepatic effects of $\mathrm{CeO}_{2} \mathrm{NPs}$, this model does not present the systemic metabolic abnormalities related to MAFLD. There are, however, few studies evaluating the effects of $\mathrm{CeO}_{2} \mathrm{NPs}$ in fatty liver associated with obesity models. Kobyliak et al. [92] studied the effects of $\mathrm{CeO}_{2} \mathrm{NPs}$ in a rat model of obesity induced by a neonatal injection of MSG that develops liver steatosis. $\mathrm{CeO}_{2} \mathrm{NPs}$ were administered orally $(1 \mathrm{mg} / \mathrm{kg}$ bw) from one month of age in two two-week courses for 3 months. Histological examination of the liver at 4 months of age showed a reduction in hepatic steatosis and lobular inflammation in the $\mathrm{CeO}_{2} \mathrm{NP}$-treated rats. Body weight, total liver lipids, and triglycerides were also significantly decreased. Rocca et al. [93] evaluated the anti-obesity potential of $\mathrm{CeO}_{2} \mathrm{NPs}$, administrating them to 10 -week-old normal Wistar rats twice a week for six weeks through i.p. injection at a dose of $0.5 \mathrm{mg} / \mathrm{kg}$. Treated rats presented a lower body weight and reduced circulating levels of insulin, leptin, glucose, and triglycerides. In comparison, recent data from our lab [94] found lower circulating triglyceride levels in 14-week-old obese Zucker rats treated with $\mathrm{CeO}_{2} \mathrm{NPS}(0.1 \mathrm{mg} / \mathrm{kg}$ twice weekly in weeks 8 and $9 ; 4 \mathrm{~nm}$ ) but did not find significant effects on the body weight or circulating levels of insulin and glucose. In addition, no significant effects of $\mathrm{CeO}_{2} \mathrm{NPs}$ on liver fat accumulation were observed by hepatic oil red staining or lipidomic analysis. Differences in the intrinsic characteristics of the nanomaterial such as size and surface states, along with their dose and route of administration, may be the basis of the discrepancy in the results between normal Wistar rats and obese Zucker rats. Importantly here, the evolution of $\mathrm{CeO}_{2} \mathrm{NPs}$ in physiological media in terms of protein corona formation and potential aggregation and/or corrosion depends on the extrinsic properties of the nanomaterials, which, in turn, depend on the characteristics on the media in which they are dispersed. Hence, different nanoparticle evolution and, thus, different biological impacts have been often observed for nanoparticles administered through different routes [15]. 


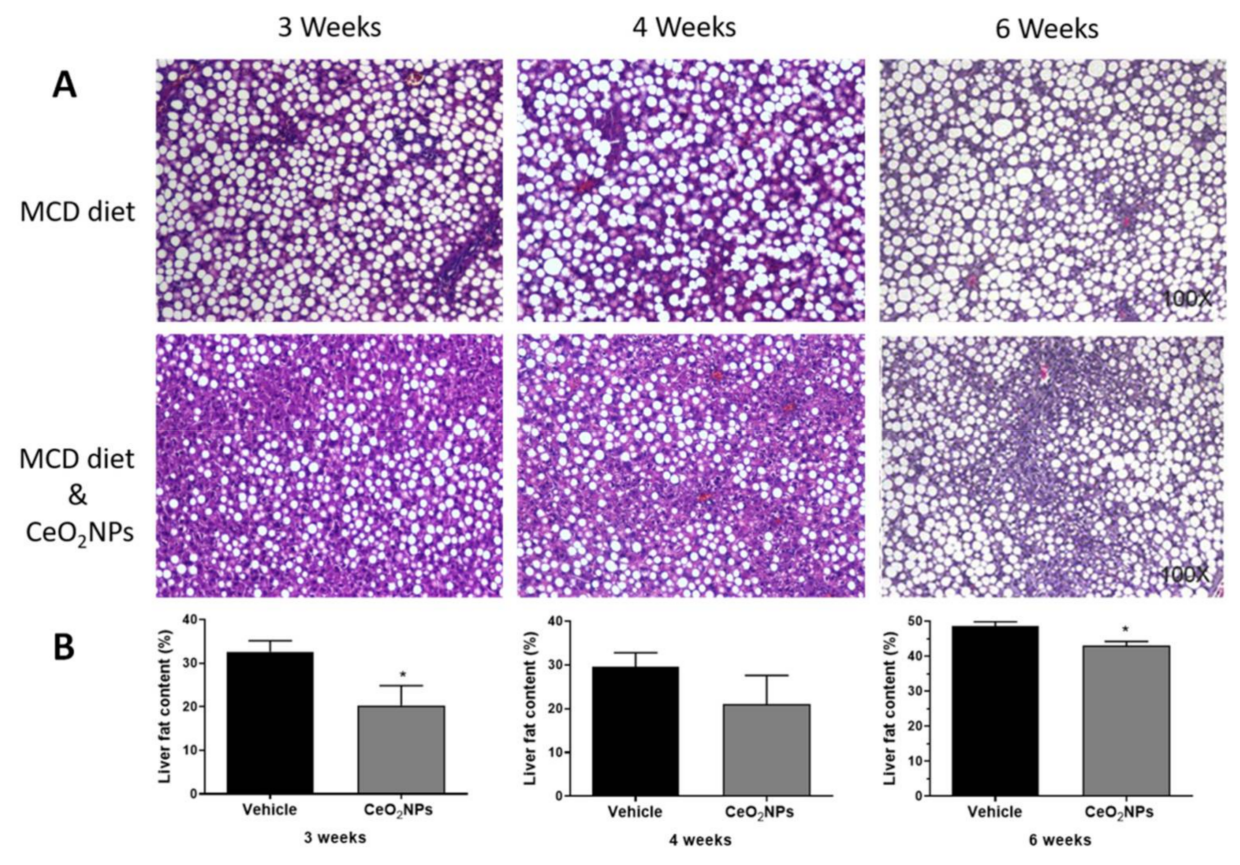

Figure 2. Effect of $\mathrm{CeO}_{2} \mathrm{NPs}$ on liver steatosis. (A) Hematoxylin and eosin representative liver sections obtained from methionine- and choline-deficient (MCD) diet Wistar rats receiving vehicle (MCD diet) or treated with $\mathrm{CeO}_{2} \mathrm{NPs}$ (MCD diet and $\mathrm{CeO}_{2} \mathrm{NPs}$ ) for 3, 4, or 6 weeks. Original magnification 100x. (B) Quantitative measurements of liver fat content (\%) in MCD diet rats receiving vehicle or treated with $\mathrm{CeO}_{2} \mathrm{NPs}$. ${ }^{*} p<0.05$ compared to MCD diet rats receiving vehicle. Unpaired Student's $t$ test (adapted from reference [84]).

To summarize, lifestyle modifications (healthy diet and physical activity) are effective in the treatment of NAFLD. However, the long-term compliance is low and, therefore, several pharmacological treatments have been proposed, although none has shown significant efficacy or long-term safety sufficient to be recommended in clinical guidelines, with the exception of vitamin $\mathrm{E}$ and pioglitazone, which may be considered in some patients with NASH $[75,76]$. The evidence shown here points to a significant therapeutic potential of $\mathrm{CeO}_{2} \mathrm{NPs}$ in MAFLD, with significant effects on lipid peroxidation and liver steatosis in different experimental conditions. In view of future clinical applications, it is important to note that vitamin E, which can be considered as a main representative of "classical" antioxidants, is recognized as the drug with the most profound antisteatohepatitic effects [95]. However, the lack of efficacy in reducing hepatic fibrosis [96] limits their clinical value. Therefore, progress in the synthesis and design of a new generation of nanoctalysts such as antioxidant-based $\mathrm{CeO}_{2}$ nanomaterials should be aimed at overcoming the limitations of classical antioxidants in MAFLD. In fact, in contrast to classical antioxidants, which have short and no targeted activity, nanocatalysts such as $\mathrm{CeO}_{2} \mathrm{NPs}$ already present significant advantages that include their long residence time in tissues and their property of not being consumed during the reaction. However, advances in controlled biodistribution, functionalization, and/or combination in a single nanostructure with complementary agents targeting several activities and biological processes may be necessary to achieve the desired complete therapeutic effect in MAFLD.

\section{Liver Inflammation}

\subsection{Inflammation in the Development of Liver Diseases}

Hepatic inflammation and sustained oxidative stress originate in response to a wide array of insults and are considered as common triggers of liver disease [97]. Following liver injury, damaged hepatocytes release a plethora of mediators such as growth factors, matrix metalloproteinases, and chemokines that promote the infiltration of immune cells and activate the apoptosis and regeneration of injured parenchymal cells [98]. HSCs also 
transdifferentiate into myofibroblast-like cells and migrate to sites of injury to secrete limited ECM.

Intracellular self-structures named damage-associated molecular patterns (DAMPs), including mitochondrial components, adenosine triphosphate (ATP), nuclear proteins, and nucleic acids, are also released in the extracellular space during injury. They are recognized by pattern recognition receptors present on immune cells such as Kupffer cells, neutrophils, and dendritic cells $[99,100]$. In response, these cells are activated and induce the transcription of signaling pathways such as nuclear factor $(\mathrm{NF})-\kappa \mathrm{B}$, orchestrating a pro-survival and pro-inflammatory response positively modulating the expression of chemoattractant and proinflammatory mediators, including interleukin 1 alpha (IL-1 $\alpha$ ), IL-6, and TNF- $\alpha$ [101]. At the same time, these agents induce the expression of adhesion molecules in the site of injury to facilitate the recruitment of more either innate or adaptive immune cells and further stimulate them, thus establishing a highly hepatotoxic feedforward cycle [102].

The overproduction of ROS and RNS during injury exceeding the buffer capacity of the cell results in mitochondrial dysfunction and DNA, lipid, and protein damage. Oxidative stress also activates signaling pathways including NF- $\mathrm{B}$, p38, ERK1/ERK2, JNK, and JAK, increasing proinflammatory gene transcription (Figure 3) [103]. In order to protect cells against injury, the elevated oxidative stress also induces the activation of the ARE, with Nrf being the master regulator [104]. Nrf2 modulates the expression of a myriad of genes such as SOD and glutathione reductase (GR), ultimately reducing the oxidative stress, cellular death, and inflammation [103].

When inflammation becomes chronic, there is a massive loss of the hepatic parenchyma; regeneration and protective pathways eventually fail; and huge quantities of ECM are secreted, leading to tissue fibrosis. Hepatic fibrosis can then further progress to cirrhosis and eventually lead to HCC [105]. Dysregulated inflammatory responses have also been associated, for instance, to hepatitis infections, alcoholic fatty liver disease, NAFLD, and ischemia/reperfusion (IR) injury [102].

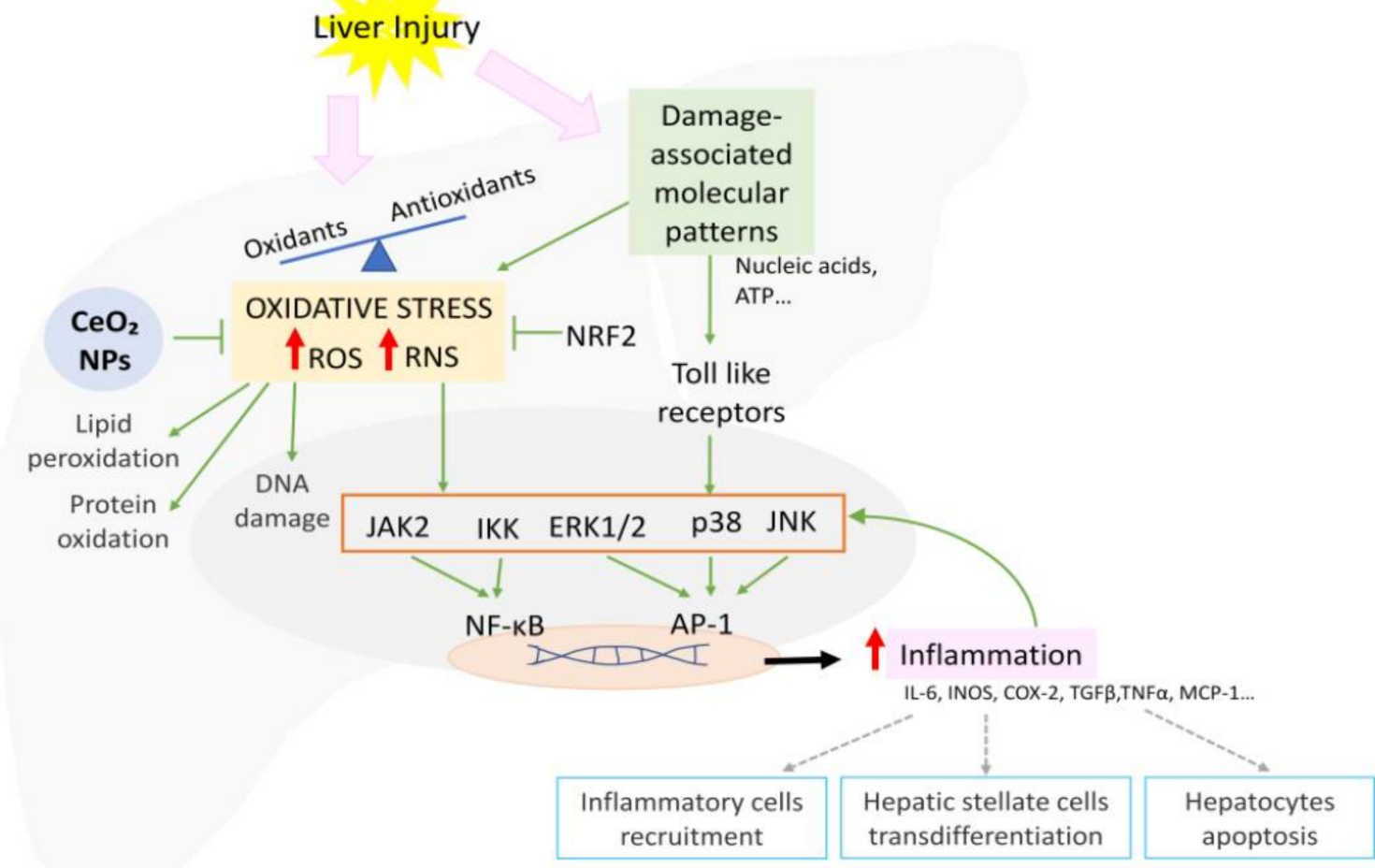

Figure 3. Schematic representation of the signaling pathways involved in oxidative stress-mediated inflammation and $\mathrm{CeO}_{2} \mathrm{NP}$ effects. 


\subsection{Cerium Oxide Nanoparticles and Hepatic Inflammation}

There is still a clinical need to develop more effective and safer therapies for most patients with liver diseases. Targeting pro-oxidant and inflammatory pathways could be a promising way to approach them, since oxidative stress has a central role in the progression of inflammation. Therefore, antioxidants are expected to interfere with proinflammatory signaling activation and subsequent tissue damage and death (Figure 3). Experimental evidence suggests that this is the case with $\mathrm{CeO}_{2} \mathrm{NPs}$, which have the potential to attenuate hepatic inflammation regardless of the stage of liver disease [32,106].

Hirst et al. [14] reported that pretreating murine macrophages with nanoceria J774A.1 decreased ROS production as well as messenger RNA and protein levels of iNOS [105]. They also showed that macrophages stimulated with LPS and interferon $\gamma$ and incubated with $\mathrm{CeO}_{2} \mathrm{NPs}$ diminished nitrate production in comparison to non-treated cells. Finally, although no differences were found in oxidative damage to DNA in mice with liverinduced toxicity by the intraperitoneal injection of $\mathrm{CCl}_{4}$ and treated with $\mathrm{CeO}_{2} \mathrm{NPs}$, animals receiving the nanoparticles showed a greater reduction in lipid peroxidation compared to $\mathrm{N}$-acetyl cysteine-treated animals [14].

In experimental rat liver fibrosis, nanoceria markedly reduced hepatic macrophage infiltration, oxidative-mediated endoplasmic reticulum stress messengers (Hspa5, Atf3), and the expression of M1-related genes (Il- $1 \beta$, Tnf- $\alpha$, iNos, and cyclooxygenase 2 (Cox2)) in comparison to vehicle-treated animals [32]. Additionally, immortalized endothelial cells from the portal vein of cirrhotic rats (CH-iPVEC) treated with CeO2NPs presented decreased Il-6 expression. Furthermore, the secretome of these $\mathrm{CH}$-iPVEC induced macrophage polarization from M1 to M2. Along this line, cirrhotic rats treated with nanoceria presented downregulated Il-6 in the portal vein [107]. In order to demonstrate whether the therapeutic properties of these NPs could be translated to human cells, a humanderived hepatocyte cell line named HepG2 was exposed to LPS and $\mathrm{H}_{2} \mathrm{O}_{2} \cdot \mathrm{CeO}_{2} \mathrm{NPs}$ reduced ROS production and modified the messenger expression of proinflammatory and oxidative stress-related genes, including iNOS, myeloperoxidase (MPO), prostaglandinendoperoxide synthase 1 (PTGS1), and neutrophil cytosol factor 2 (Ncf2) [108]. $\mathrm{CeO}_{2} \mathrm{NPs}$ were also demonstrated to be powerful anti-inflammatory agents in experimental NAFLD. Their administration in rats with MSG-induced obesity resulted in a lower serum amount of IL-12 B p 40 and IL- $1 \beta$ and the restoration of the levels of anti-inflammatory mediators IL-10, IL-4, and TGF- $\beta$ [109]. In line with these results, Carvajal et al. [85] showed that in animals fed a methionine choline-deficient diet, these nanoparticles not only decreased lipid peroxidation but also attenuated liver inflammatory markers such as C-C Motif Chemokine Ligand 5 (CCL5) and Il-1 $\beta$, as well as diminishing the proportion of proinflammatory fatty acids. Interestingly, cultured 3D Hep G2 cells challenged with a mixture of palmitic and oleic acid to resemble lipid-induced inflammation in humans showed a significant reduction in the release of proinflammatory cytokines, such as TNF- $\alpha$ and IL- 8 , when treated with a complex of zinc salt of mefenamic acid, hydroxypropyl- $\beta$ cyclodextrin, and $\mathrm{CeO}_{2} \mathrm{NPs}$ [109].

During the development of chronic liver disease, hepatocytes can eventually transform to a malignant phenotype and lead to the development of HCC, an inflammation-induced cancer. Adebayo et al. [110] showed that prophylaxis with $\mathrm{CeO}_{2} \mathrm{NPs}$ yielded a reduction in iNos and COX-2 expression in the liver of mice administered with diethylnitrosamine (DEN). In addition, rats with chronically DEN-induced HCC and treated with nanoceria presented reduced macrophage infiltration and M2 marker gene expression (Il-1 $\beta$, TNF- $\alpha$, iNOS, and COX-2). The hepatic phosphoproteomic analysis of these animals revealed that the nanoparticles also altered the phosphorylation of genes related to cell-cell and cell-matrix adhesion [111].

Significant complications due to end-stage chronic liver disease eventually lead to liver surgery or transplantation. The restoration of blood flow to a previously ischemic liver post-surgery leads to an exacerbation of cellular dysfunction and death [112]. Prophylactic treatment with nanoceria decreased hepatic ischemia reperfusion injury cell death by 
attenuating the levels of the inflammatory mediators myoglobin, macrophage derived chemokine, plasminogen activator inhibitor 1 , macrophage inflammatory protein 2 , and Von Willebrand factor [113].

Liver dysfunction secondary to other diseases could also potentially be treated with $\mathrm{CeO}_{2} \mathrm{NPs}$. Sepsis is the most common cause of mortality in intensive care units and one of its more serious complications is liver dysfunction, which leads to disease progression and death [114]. LPS-induced sepsis resulted in high animal mortality, systemic inflammation and liver damage. Increased survival in rats treated with $\mathrm{CeO}_{2} \mathrm{NPs}$ was associated with a decreased serum inflammation. In the liver, nanoceria also ameliorated LPS-induced morphology distortion and diminished the protein expression of iNos, Hmgb1, and MyD88, as well as the phosphorylation of p38 MAPKp44/42-MAPK [115]. In agreement with these results, Hashlem et al. [83] found that $\mathrm{CeO}_{2} \mathrm{NPs}$ protected against liver injury in D-GALN/LPS-induced hepatotoxicity. Treatment with the nanoparticles reduced lipid peroxidation and iNos expression while augmenting cytosolic Nrf2 and, as a consequence, reducing heme oxygenase 1 (HO-1).

In summary, a compelling amount of data strongly indicate that $\mathrm{CO}_{2} \mathrm{NPs}$ behave as powerful anti-inflammatory agents. However, further studies are necessary to accurately define the signaling pathways accounting for this phenomenon.

\section{Hepatocellular Carcinoma}

Primary liver cancer includes HCC, cholangiocarcinoma, and other types of liver cancer. Among primary liver cancers, HCC is the most frequent histological subtype in approximately $70 \%$ to $80 \%$ of cases [116]. Patients with liver cancer are often asymptomatic in early stages and do not present with typical liver symptoms, such as jaundice, liver failure, and ascites, until they progress to advanced stages.

Globally, HCC is the fifth most common cancer type and the third leading cause of cancer-related death worldwide [117], with more than one million cases diagnosed each year around the world [117]. HCC is a tumor associated with chronic inflammation and fibrosis arising from different etiologies, including hepatitis $\mathrm{B}$ and $\mathrm{C}$ and alcoholic and nonalcoholic fatty liver diseases [118,119]. In Western countries, NAFLD is one of the most common liver diseases that promotes the development of HCC [120].

\subsection{Oxidative Stress and Inflammation Mediate HCC Development}

Oxidative stress has a key pathological role contributing to the initiation and progression of HCC [121]. When the redox equilibrium is disrupted, either by increased ROS production and/or due to an insufficient response of natural defense systems, key cellular processes such as proliferation and apoptosis are modified [18,122].

Regardless of their etiopathogenic origin and the different molecular mechanisms inherent to each etiology, chronic liver inflammation and the resulting cirrhotic microenvironment are the main factors involved in the onset and progression of HCC [118]. About $80 \%$ to $90 \%$ of HCC cases originate from cirrhosis caused by chronic inflammation of the liver [123], with death of epithelial cells being the main trigger of the inflammation associated with hepatocarcinogenesis. The pathways which contribute to inflammation-mediated hepatocarcinogenesis include cytokine signaling (TNF- $\alpha$, IL-6, NF-kB, JNK, STAT3), innate immune signaling, and adaptive immunity [118].

\subsection{Current Therapeutic Approaches in HCC}

Cancer is associated with a poor prognosis. First-line treatment methods in the management of HCC include surgical interventions, cytotoxic chemotherapies and radiation, liver transplantation, microwave ablation, percutaneous ethanol injection, radiofrequency ablation, radiation therapy, supportive care, surgical resection, transcatheter arterial chemoembolization, high-intensity focused ultrasound ablation, percutaneous acetic acid injection, percutaneous cryosurgery, sorafenib, transcatheter arterial chemotherapy, transarterial radioembolization, intra-arterial infusion chemotherapy, systemic chemotherapy, 
portal vein chemotherapy, portal vein embolization, and their combinations [124]. Conventional therapies can be ineffective and the coexistence of cirrhosis and HCC in the same patient complicates possible therapeutic strategies. The current systemic treatments of HCC are based on molecular targeted therapies. Sorafenib, lenvatinib, cabozatinib, or regorafenib, as well as the antiangiogenic antibody ramucirumab, are considered effective therapies in patients with advanced HCC [125]. However, clinical trials have found only a modest improvement in survival, and overall the median survival continues to be approximately 1 year [126]. Thus, although the new drugs available improve clinical outcomes, the still insufficient effects on disease progression and the emergence of resistance episodes reveal the need to develop new therapies for HCC $[127,128]$.

In this scenario, the development of novel antioxidants able to circumvent the limitation of the classical antioxidants is a logical therapeutic approach. Antioxidants have been described as substances that delay, prevent, or remove oxidative damage to a target. Many antioxidant compounds, enzymes, and nitric oxide inhibitors have been studied for treating chronic inflammation and cancer, some of which have also been evaluated in clinical trials. However, the results to date are suboptimal, mainly due to their low systemic bioavailability and insufficient levels at the target sites.

Previous studies in animals and in liver cancer cells demonstrated that antioxidants are treated as one of the promising strategies to prevent liver cancer [129]. Furthermore, it has been reported that the combination of certain chemotherapeutic drugs and antioxidants could reduce drug resistance, sensitizing the liver cancer cells to chemotherapeutics and thereby improving the efficacy of anti-cancer therapy [130].

\section{3. $\mathrm{CeO}_{2} \mathrm{NPs}$ as a New Therapeutic Tool in HCC}

Nanotechnology has achieved relevance in biomedical research and nanomedicine has emerged as a new treatment option for tumor therapy [131,132]. Among various nanoparticles, $\mathrm{CeO}_{2} \mathrm{NPs}$ have shown promise in a number of applications $[133,134]$.

To act as therapeutic agents, $\mathrm{CeO}_{2} \mathrm{NPs}$ must have a large surface area and reactivity, as well as a wide biocompatibility without systemic toxicity for normal cells and tissues. Different studies have shown that $\mathrm{CeO}_{2} \mathrm{NPs}$ can be toxic to cancer cells by increasing the level of ROS or by targeting the nuclei of tumor cells without affecting the surrounding normal tissue $[135,136]$. $\mathrm{CeO}_{2} \mathrm{NPs}$ have also been reported to have anti-invasive properties and the ability to sensitize cancer cells to radiation therapy and chemotherapy [137-139]. On the other hand, it has been reported that $\mathrm{CeO}_{2} \mathrm{NPs}$ could prevent metastasis and inhibit apoptosis by repressing the ASK1-P38/JNK-NF-кB signaling pathway [138].

More recently, Fernández-Varo et al. [111] considered that $\mathrm{CeO}_{2} \mathrm{NPs}$ could be an nanoparticle-based therapy platform in HCC. HCC was induced in rats by the i.p. chronic administration of DEN for 16 weeks. Rats with $\mathrm{HCC}$ were treated with $\mathrm{CeO}_{2} \mathrm{NPs}$ i.v. at weeks 16 and 17. The analysis of tissue distribution showed that nanoceria was mainly accumulated in the liver and significantly decreased hepatic macrophage infiltration and reduced the inflammatory M1 gene expression profile, such as IL1 $\beta$, TNF $\alpha$, IL6, iNOS, and COX-2. Nanoceria treatment increased liver apoptotic activity, while cell proliferation was attenuated. The authors also investigated the effects of $\mathrm{CeO}_{2} \mathrm{NPs}$ on kinase-driven signaling pathways using mass spectrometry. Phosphoproteomic analysis revealed that $\mathrm{CeO}_{2} \mathrm{NPs}$ affected the phosphorylation of proteins mainly related to cell adhesion and RNA splicing. The analysis of the effect of $\mathrm{CeO}_{2} \mathrm{NPs}$ on hepatic lipid metabolism showed decreased phosphatidylcholine-derived arachidonic acid and a reversal in the HCC-induced increase in linoleic acid in several lipid components. Furthermore, $\mathrm{CeO}_{2} \mathrm{NPs}$ decreased the serum alpha-protein levels and improved the survival of HCC rats (Figure 4). The effect of $\mathrm{CeO}_{2} \mathrm{NPs}$ on overall survival was similar to that observed with sorafenib, which indicates that these nanoparticles are at least as effective as sorafenib under the conditions studied. On the other hand, the intracellular uptake of $\mathrm{CeO}_{2} \mathrm{NPs}$ by human ex vivo perfused livers and human hepatocytes was analyzed. The results obtained demonstrated nanoceria uptake by ex vivo perfused human livers and in vitro human hepatocytes. These results 


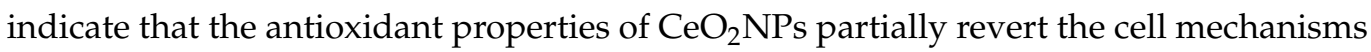
involved in tumor progression and significantly increase survival in HCC rats. These findings suggest that $\mathrm{CeO}_{2} \mathrm{NPs}$ alone, or in combination with the current molecular targeted therapies, could be effective in stopping or attenuating tumoral progression in patients with HCC [111].

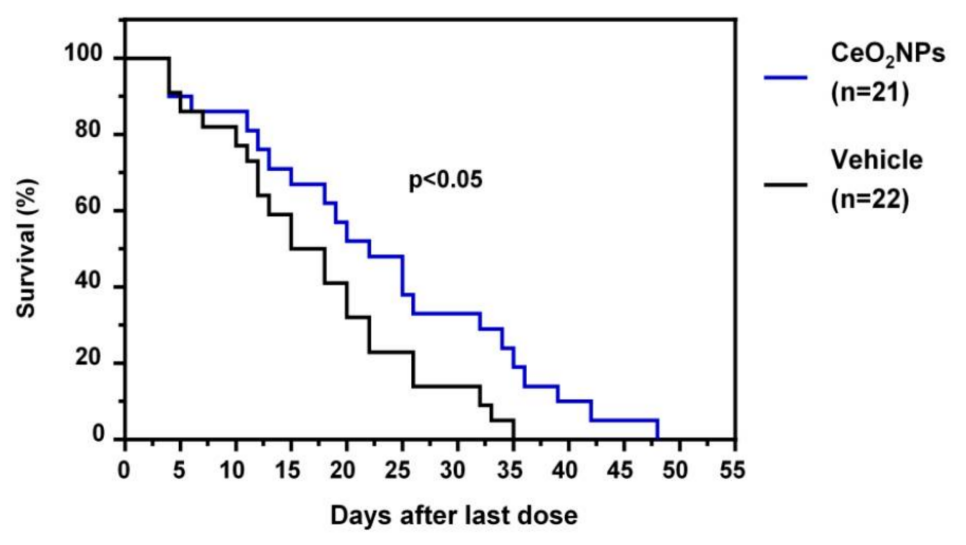

Figure 4. Effect of $\mathrm{CeO}_{2} \mathrm{NPs}$ on survival. $\mathrm{HCC}$ rats randomly received two weekly doses of $\mathrm{CeO}_{2} \mathrm{NPs}$ or vehicle through the tail vein at weeks 16 and 17, and their survival was analyzed (adapted from reference [111]).

Despite these promising biomedical applications, most of the $\mathrm{CeO}_{2} \mathrm{NPs}$ used in these previous studies were naked or weakly protected by surfactants. This circumstance causes the appearance of many difficulties in in vivo practice, such as the aggregation and elimination of particles by the mononuclear phagocyte system. This situation could cause a decrease in activity and a shorter circulation time of the nanoparticles. To avoid this situation, hydrophilic polymers such as polyethylene glycol (PEG) have been used in an attempt to construct surface coatings of $\mathrm{CeO}_{2} \mathrm{NPs}$ with a better nanoparticle stability and modified surface charges. PEG is considered to be the most effective polymer for improving biocompatibility and adapting the surface charge of inorganic nanoparticles [140]. In this sense, alendronate was found to be an ideal anchor for inserting PEG, specifically PEG600, on the surface of $\mathrm{CeO}_{2} \mathrm{NPs}$ and obtaining improved nanoparticle stability and reduced cytotoxicity in normal human liver cells [141].

\section{Conclusions}

Although our knowledge of the biological protective properties of $\mathrm{CeO}_{2} \mathrm{NPs}$ against free radicals dates back less than two decades, and that the first studies in the field of hepatology are less than one decade old, there is abundant evidence showing the therapeutic potential of this nanomaterial in liver diseases. In fact, oxidative stress is considered a key pathogenic mechanism contributing to the initiation and progression of most liver diseases and, therefore, strategies aimed at reducing free radicals are of great interest. In contrast to classical antioxidants, which have short and no targeted activity, $\mathrm{CeO}_{2} \mathrm{NPs}$ present multienzimatic activity, high liver tropism, long residence time in liver tissue, and lack of consumption during the redox reactions, which significantly increase their potential therapeutic activity in liver diseases. In agreement with this, protective effects have been found in different experimental models of liver disease, including liver fibrosis, steatohepatitis, hepatocellular carcinoma and liver regeneration. Moreover, studies generally do not show toxicity under standard therapeutic doses. Nonetheless, some aspects have yet to be clarified. Thus, although the mechanisms of action are beginning to be characterized, they still need to be completely elucidated and understood. Future work also includes characterization of the evolution of nanomaterial in different in vivo scenarios, the knowledge of their cellular and subcellular distribution, and possibilities of controlled bioditribution and 
functionalization. Overall, current evidence places CeO2NPs as a simple and powerful therapeutic approach for highly prevalent liver diseases.

Author Contributions: All authors contributed to writing and editing the original draft manuscript: G.C.; M.P.; E.C.; I.P.; G.F.-V.; M.M.-R.; V.P.; W.J.—contributed equally. All authors have read and agreed to the published version of the manuscript.

Funding: Researches referred by the authors were funded by Fundació La Marató de TV3 (grant Marató 120930), Dirección General de Investigación Científica y Técnica (SAF15-64126-R and RTI2018094734-B-C21, PID2019-105502RB, and BES-2017-08023), Agència de Gestió d'Ajuts Universitaris i de Recerca (SGR 2017/2019), and Instituto de Salud Carlos III (FIS PI15-00077 and FIS PI19-00774) co-financed by FEDER, European Union, "A way of making Europe" and the National Natural Science Foundation of China (31950410536). The Centro de Investigación Biomédica en Red de Enfermedades Hepáticas y Digestivas (CIBERehd) is funded by the Instituto de Salud Carlos III.

Acknowledgments: In this section, you can acknowledge any support given which is not covered by the author contribution or funding sections. This may include administrative and technical support, or donations in kind (e.g., materials used for experiments).

Conflicts of Interest: The authors declare no conflict of interest. The funders had no role in the design of the study; in the collection, analysis, or interpretation of data; in the writing of the manuscript; or in the decision to publish the results.

\section{Abbreviations}

Acetaminophen

APAP

adenosine triphosphate

ATP

antioxidant response element

ARE

augmenter of liver regeneration

ALR

carbon tetrachloride

$\mathrm{CCl}_{4}$

cerium (IV) oxide

cerium (III) oxide

$\mathrm{CeO}_{2}$

cerium oxide nanoparticles

$\mathrm{Ce}_{2} \mathrm{O}_{3}$

cyclooxygenase 2

$\mathrm{CeO} 2 \mathrm{NPs}$

damage associated molecular patterns

Cox-2

desferoxamine

DAMPs

diethylnitrosamine

DES

extracellular matrix

DEN

fatty acid synthase

ECM

glutamate-cysteine ligase, catalytic subunit

FASN

glutathione

GCLC

glutathione reductase

GSH

glutathione-S-transferase

GR

hepatic stellate cells

GST

hepatocyte growth factor

HSCs

hepatocellular carcinoma

HGF,

heme oxygenase 1

$\mathrm{HCC}$

IL-6 receptor

HO-1

inducible nitric oxide synthase iNOS

interleukin 1 alpha IL- $1 \alpha$

interleukin $6 \quad$ IL-6

intraperitoneally i.p.

intravenously i.v.

IkB kinase IKK

Janus xineses JAK

knockout $\quad \mathrm{KO}$

malondialdehyde MDA

methionine choline deficient MCD 


$\begin{array}{ll}\text { mitogen-activated protein kinase } & \text { MAPK } \\ \text { metabolic dysfunction-associated fatty liver disease } & \text { MAFLD } \\ \text { myeloperoxidase } & \text { MPO } \\ \text { NADPH quinine oxidoreductase 1 } & \text { NQO1 } \\ \text { N-acetyl cysteine } & \text { NAC } \\ \text { nicotinamide adenine dinucleotide phosphate } & \text { NADPH } \\ \text { NF-E2-related factor 2 } & \text { Nrf2 } \\ \text { neutrophil cytosol factor } 2 & \text { Ncf2 } \\ \text { nitric oxide } & \text { NO } \\ \text { non-alcoholic fatty liver disease } & \text { NAFLD } \\ \text { non-alcoholic steatohepatitis } & \text { NASH } \\ \text { nuclear factor } & \text { NF } \\ \text { nuclear factor kappa-light-chain enhancer of activated } \beta \text { cells } & \text { NF-kB } \\ \text { partial hepatectomy } & \text { PHx } \\ \text { polyethylene glycol } & \text { PEG } \\ \text { prostaglandin-endoperoxide synthase 1 } & \text { PTGS1 } \\ \text { reactive oxygen species } & \text { ROS } \\ \text { reactive nitrogen species } & \text { RNS } \\ \text { S6 kinase signal-transduction pathways } & \text { TOR } \\ \text { suppressor of cytokine signaling-3 } & \text { SOCS-3 } \\ \text { superoxide dismutase } & \text { SOD } \\ \text { tempol } & \text { TEM } \\ \text { thiobarbituric acid reactive substances } & \text { TBARS } \\ \text { transforming growth factor alpha } & \text { TGF } \alpha \\ \text { tumor necrosis factor alpha } & \text { TNF } \alpha \\ \text { urokinase-type plasminogen activator } & \text { uPA } \\ \text { vascular endothelial growth factor } & \text { VEGF }\end{array}$

\section{References}

1. Montini, T.; Melchionna, M.; Monai, M.; Fornasiero, P. Fundamentals and Catalytic Applications of CeO ${ }_{2}-B_{a}$ ased. Mater. Chem. Rev. 2016, 116, 5987-6041. [CrossRef] [PubMed]

2. Strawn, E.T.; Cohen, C.A.; Rzigalinski, B.A. Cerium oxide nanoparticles increase lifespan and protect against free radical-mediated toxicity. FASEB J. 2006, 20, A1356. [CrossRef]

3. Rzigalinski, B.A. Nanoparticles and Cell Longevity. Technol. Cancer Res. Treat. 2005, 4, 651-659. [CrossRef]

4. Rzigalinski, B.A.; Meehan, K.; Davis, R.M.; Xu, Y.; Miles, W.C.; Cohen, C.A. Radical nanomedicine. Nanomedicine 2006, 1, $399-412$. [CrossRef] [PubMed]

5. Rzigalinski, B.A.; Seal, S.; Bailey, D.; Patil, S. Cerium Oxide Nanoparticles and Use in Enhancing Cell Survivability. U.S. Patent U.S. 7534453B1, 5 September 2002.

6. Rzigalinski, B.; Bailey, D.; Chow, L.; Kuiry, S.C.; Patil, S.; Merchant, S.; Seal, S. Cerium oxide nanoparticles increase the lifespan of cultured brain cells and protect against free radical and mechanical trauma. FASEB J. 2003, 17, A606.

7. Fry, R.; Ellison, A.; Colon, J.; Merchant, S.; Kuiry, S.; Patil, S.; Seal, S.; Rzigalinski, B.A. Engineered Oxide Nanoparticles Protect Against Neuronal Damage Associated with In Vitro Trauma. Abstracts from the 21st Annual National Neurotrauma Society Symposium (P310). J. Neurotrauma 2003, 20, 1105. [CrossRef]

8. Callaghan, P.; Colon, J.; Merchant, S.; Kuiry, S.; Patil, S.; Seal, S.; Rzigalinski, B.A. Deleterious effects of microglia activated by in vitro trauma are blocked by engineered oxide nanoparticles. Abstracts from the 21st Annual National Neurotrauma Society Symposium (P120). J. Neurotrauma 2003, 20, 1057. [CrossRef]

9. Tarnuzzer, R.W.; Colon, J.; Patil, S.; Seal, S. Vacancy engineered ceria nanostructures for protection from radiation-induced cellular damage. Nano Lett. 2005, 5, 2573-2577. [CrossRef] [PubMed]

10. Schubert, D.; Dargusch, R.; Raitano, J.; Chan, S.W. Cerium and yttrium oxide nanoparticles are neuroprotective. Biochem. Biophys. Res. Commun. 2006, 342, 86-91. [CrossRef] [PubMed]

11. Das, M.; Patil, S.; Bhargava, N.; Kang, J.-F.; Riedel, L.M.; Seal, S.; Hickman, J.J. Auto-catalytic ceria nanoparticles offer neuroprotection to adult rat spinal cord neurons. Biomaterials 2007, 28, 1918-1925. [CrossRef] [PubMed]

12. Chen, J.P.; Patil, S.; Seal, S.; McGinnis, J.F. Rare earth nanoparticles prevent retinal degeneration induced by intracellular peroxides. Nat. Nanotechnol. 2006, 1, 142-150. [CrossRef]

13. Niu, J.L.; Azfer, A.; Rogers, L.M.; Wang, X.H.; Kolattukudy, P.E. Cardioprotective effects of cerium oxide nanoparticles in a transgenic murine model of cardiomyopathy. Cardiovasc. Res. 2007, 73, 549-559. [CrossRef] [PubMed]

14. Hirst, S.M.; Karakoti, A.; Singh, S.; Self, W.; Tyler, R.; Seal, S.; Reilly, C.M. Bio-distribution and in vivo antioxidant effects of cerium oxide nanoparticles in mice. Environ. Toxicol. 2013, 28, 107-118. [CrossRef] [PubMed] 
15. Casals, E.; Zeng, M.; Parra-Robert, M.; Fernández-Varo, G.; Morales-Ruiz, M.; Jiménez, W.; Puntes, V.; Casals, G. Cerium Oxide Nanoparticles: Advances in Biodistribution, Toxicity, and Preclinical Exploration. Small 2020, 16, 1907322. [CrossRef] [PubMed]

16. Esch, F.; Fabris, S.; Zhou, L.; Montini, T.; Africh, C.; Fornasiero, P.; Comelli, G.; Rosei, R. Electron localization determines defect formation on ceria substrates. Science 2005, 309, 752-755. [CrossRef] [PubMed]

17. Halliwell, B. Reactive Species and Antioxidants. Redox Biology Is a Fundamental Theme of Aerobic Life. Plant Physiol. 2006, 141, 312-322. [CrossRef] [PubMed]

18. Brieger, K.; Schiavone, S.; Miller, F.J., Jr.; Krause, K.H. Reactive oxygen species: From health to disease. Swiss Med. Wkly. 2012, 142, w13659. [CrossRef]

19. Kohchi, C.; Inagawa, H.; Nishizawa, T.; Soma, G.-I. ROS and Innate Immunity. Anticancer Research 2009, 29, 817-821. [PubMed]

20. Hakim, J. Reactive oxygen species and inflammation. Comptes Rendus Seances Soc. Biol. Ses Fil. 1993, 187, $286-295$.

21. Vaziri, N.D.; Rodriguez-Iturbe, B. Mechanisms of disease: Oxidative stress and inflammation in the pathogenesis of hypertension. Nat. Clin. Pract. Nephrol. 2006, 2, 582-593. [CrossRef]

22. Biswas, S.K. Does the Interdependence between Oxidative Stress and Inflammation Explain the Antioxidant Paradox? Oxid. Med. Cell. Longev. 2016, 2016, 9. [CrossRef] [PubMed]

23. Halliwell, B. The antioxidant paradox: Less paradoxical now? Br. J. Clin. Pharm. 2013, 75, 637-644. [CrossRef] [PubMed]

24. Li, S.; Hong, M.; Tan, H.-Y.; Wang, N.; Feng, Y. Insights into the Role and Interdependence of Oxidative Stress and Inflammation in Liver Diseases. Oxid. Med. Cell. Longev. 2016, 4234061. [CrossRef] [PubMed]

25. Korsvik, C.; Patil, S.; Seal, S.; Self, W. Superoxide dismutase mimetic properties exhibited by vacancy engineered ceria nanoparticles. Chem. Commun. 2007, 1056-1058. [CrossRef] [PubMed]

26. Heckert, E.; Karakoti, A.; Seal, S.; Self, W. The role of cerium redox state in the SOD mimetic activity of nanoceria. Biomaterials 2008, 29, 2705-2709. [CrossRef] [PubMed]

27. Pirmohamed, T.; Dowding, J.; Singh, S.; Wasserman, B.; Heckert, E.; Karakoti, A.; King, J.; Seal, S.; Self, W. Nanoceria exhibit redox state-dependent catalase mimetic activity. Chem. Commun. 2010, 46, 2736-2738. [CrossRef]

28. Cafun, J.D.; Kvashnina, K.O.; Casals, E.; Puntes, V.F.; Glatzel, P. Absence of $\mathrm{Ce}^{3+}$ sites in chemically active colloidal ceria nanoparticles. ACS Nano 2013, 7, 10726-10732. [CrossRef] [PubMed]

29. Heckert, E.G.; Seal, S.; Self, W.T. Fenton-Like Reaction Catalyzed by the Rare Earth Inner Transition Metal Cerium. Environ. Sci. Technol. 2008, 42, 5014-5019. [CrossRef]

30. Dowding, J.; Dosani, T.; Kumar, A.; Seal, S.; Self, W. Cerium oxide nanoparticles scavenge nitric oxide radical ((NO)-N-center dot). Chem. Commun. 2012, 48, 4896-4898. [CrossRef] [PubMed]

31. Xu, C.; Qu, X. Cerium oxide nanoparticle: A remarkably versatile rare earth nanomaterial for biological applications. NPG Asia Mater. 2014, 6, e90. [CrossRef]

32. Oro, D.; Yudina, T.; Fernandez-Varo, G.; Casals, E.; Reichenbach, V.; Casals, G.; de la Presa, B.; Sandalinas, S.; Carvajal, S.; Puntes, V.; et al. Cerium oxide nanoparticles reduce steatosis, portal hypertension and display anti-inflammatory properties in rats with liver fibrosis. J. Hepatol. 2016, 64, 691-698. [CrossRef]

33. Muhammad, F.; Wang, A.; Qi, W.; Zhang, S.; Zhu, G. Intracellular Antioxidants Dissolve Man-Made Antioxidant Nanoparticles: Using Redox Vulnerability of Nanoceria to Develop a Responsive Drug Delivery System. ACS Appl. Mater. Interfaces 2014, 6, 19424-19433. [CrossRef]

34. Yang, B.; Chen, Y.; Shi, J. Nanocatalytic Medicine. Adv. Mater. 2019, 31, 1901778. [CrossRef] [PubMed]

35. Yang, B.; Chen, Y.; Shi, J. Reactive Oxygen Species (ROS)-Based Nanomedicine. Chem. Rev. 2019, 119, 4881-4985. [CrossRef]

36. Wang, H.; Wan, K.; Shi, X. Recent Advances in Nanozyme Research. Adv. Mater. 2018, 31, 1805368. [CrossRef] [PubMed]

37. Ghorbani, M.; Derakhshankhah, H.; Jafari, S.; Salatin, S.; Dehghanian, M.; Falahati, M.; Ansari, A. Nanozyme antioxidants as emerging alternatives for natural antioxidants: Achievements and challenges in perspective. Nano Today 2019, 100775. [CrossRef]

38. Liu, Y.; Shi, J. Antioxidative nanomaterials and biomedical applications. Nano Today 2019, 27, 146-177. [CrossRef]

39. Howes, R.M. The free radical fantasy: A panoply of paradoxes. Ann. NY Acad. Sci. 2006, 1067, 22-26. [CrossRef] [PubMed]

40. Hutson, S. Experts urge a more measured look at antioxidants. Nat. Med. 2008, 14, 795. [CrossRef]

41. Higgins, G.M.; Anderson, R.M. Experimental pathology of the liver. I. Restoration of the liver of the white rat following partial surgical removal. Arch. Pathol. 1931, 12, 186-202.

42. Taub, R. Liver regeneration: From myth to mechanism. Nat. Rev. Mol. Cell Biol. 2004, 5, 836-847. [CrossRef] [PubMed]

43. Michalopoulos, G.K.; Bhushan, B. Liver regeneration: Biological and pathological mechanisms and implications. Nat. Rev. Gastroenterol. Hepatol. 2021, 18, 40-55. [CrossRef] [PubMed]

44. Michalopoulos, G.K.; DeFrances, M.C. Liver regeneration. Science 1997, 276, 60-66. [CrossRef]

45. Íimuro, Y.; Nishiura, T.; Hellerbrand, C.; Behrns, K.E.; Schoonhoven, R.; Grisham, J.W.; Brenner, D.A. NFkB prevents apoptosis and liver dysfunction during liver regeneration. J. Clin. Investig. 1998, 101, 802-811. [CrossRef] [PubMed]

46. Maeda, S.; Chang, L.; Li, Z.W.; Luo, J.L.; Leffert, H.; Karin, M. IKK $\beta$ is required for prevention of apoptosis mediated by cell-bound but not by circulating TNF $\alpha$. Immunity 2003, 19, 725-737. [CrossRef]

47. Kirillova, I.; Chaisson, M.; Fausto, N. Tumor necrosis factor induces DNA replication in hepatic cells through nuclear factor $\kappa \mathrm{B}$ activation. Cell Growth Differ. 1999, 10, 819-828.

48. Yamada, Y.; Fausto, N. Deficient liver regeneration after carbon tetrachloride injury in mice lacking type 1 but not type 2 tumor necrosis factor receptor. Am. J. Pathol. 1998, 152, 1577-1589. [PubMed] 
49. Mars, W.M.; Liu, M.L.; Kitson, R.P.; Goldfarb, R.H.; Gabauer, M.K.; Michalopoulos, G.K. Immediate early detection of urokinase receptor after partial hepatectomy and its implications for initiation of liver regeneration. Hepatology 1995, 21, 1695-1701. [CrossRef] [PubMed]

50. Currier, A.R.; Sabla, G.; Locaputo, S.; Melin-Aldana, H.; Degen, J.L.; Bezerra, J.A. Plasminogen directs the pleiotropic effects of uPA in liver injury and repair. Am. J. Physiol. Gastrointest. Liver Physiol. 2003, 284, 508-515. [CrossRef]

51. Michalopoulos, G.K. Liver regeneration. J. Cell Physiol. 2007, 203, 286-300. [CrossRef] [PubMed]

52. Fausto, N. Liver regeneration. J. Hepatol. 2000, 32, 19-31. [CrossRef]

53. Fausto, N. Liver regeneration: From laboratory to clinic. Liver Transpl. 2001, 7, 835-844. [CrossRef] [PubMed]

54. Campbell, J.S.; Prichard, L.; Schaper, F.; Schmitz, J.; Stephenson-Famy, A.; Rosenfeld, M.E.; Argast, G.M.; Heinrich, P.C.; Fausto, N. Expression of suppressors of cytokine signaling during liver regeneration. J. Clin. Investig. 2001, 107, 1285-1292. [CrossRef] [PubMed]

55. Wüstefeld, T.; Rakemann, T.; Kubicka, S.; Manns, M.P.; Trautwein, C. Hyperstimulation with interleukin 6 inhibits cell cycle progression after hepatectomy in mice. Hepatology 2000, 32, 514-522. [CrossRef] [PubMed]

56. Chart, R.S.; Price, D.T.; Sue, S.R.; Meyers, W.C.; Jirtle, R.L. Down-regulation of transforming growth factor beta receptor type I, II, and III during liver regeneration. Am. J. Surg. 1995, 169, 126-132. [CrossRef]

57. Derynck, R.; Zhang, Y.E. Smad-dependent and Smad-independent pathways in TGF $\beta$. Nature 2003, 425, 577-584. [CrossRef] [PubMed]

58. Mello, T.; Zanieri, F.; Ceni, E.; Galli, A. Oxidative stress in the healthy and wounded hepatocyte: A cellular organelles perspective. Oxid. Med. Cell. Longev. 2016. [CrossRef] [PubMed]

59. Li, S.; Tan, H.Y.; Wang, N.; Zhang, Z.J.; Lao, L.; Wong, C.W.; Feng, Y. The role of oxidative stress and antioxidants in liver diseases. Int. J. Mol. Sci. 2015, 16, 26087-26124. [CrossRef] [PubMed]

60. Cichoz-Lach, H.; Michalak, A. Oxidative stress as a crucial factor in liver diseases. World J. Gastroenterol. 2014, $20,8082-8091$. [CrossRef]

61. Edeas, M.; Attaf, D.; Mailfert, A.S.; Nasu, M.; Joubet, R. Réaction de Maillard, mitochondrie et stress oxydatif: Quel rôle pour les antioxydants? Pathol. Biol. 2010, 58, 220-225. [CrossRef] [PubMed]

62. Majima, J.P.; Indo, H.; Suenaga, S.; Matsui, H.; Yen, H.-C.; Ozawa, T. Mitochondria as Possible Pharmaceutical Targets for the Effects of Vitamin E and its Homologues in Oxidative Stress-Related Diseases. Curr. Pharm. Des. 2011, 17, 2190-2195. [CrossRef] [PubMed]

63. Sanchez-Valle, V.C.; Chavez-Tapia, N.; Uribe, M.; Mendez-Sanchez, N. Role of Oxidative Stress and Molecular Changes in Liver Fibrosis: A Review. Curr. Med. Chem. 2012, 19, 4850-4860. [CrossRef] [PubMed]

64. Murakami, S.; Motohashi, H. Roles of Nrf2 in cell proliferation and differentiation. Free Radic. Biol. Med. 2015, 88, 168-178. [CrossRef] [PubMed]

65. Barnouin, K.; Dubuisson, M.L.; Child, E.S.; De Mattos, S.F.; Glassford, J.; Medema, R.H.; Mann, D.J.; Lam, E.W.F. $\mathrm{H}_{2} \mathrm{O}_{2}$ induces a transient multi-phase cell cycle arrest in mouse fibroblasts through modulating cyclin D and p21Cip1 expression. J. Biol. Chem. 2002, 277, 13761-13770. [CrossRef] [PubMed]

66. Sun, S.; Xie, F.; Xu, X.; Cai, Q.; Zhang, Q.; Cui, Z.; Zheng, Y.; Zhou, J. Advanced oxidation protein products induce S-phase arrest of hepatocytes via the ROS-dependent, $\beta$-catenin-CDK2-mediated pathway. Redox Biol. 2018, 14, 338-353. [CrossRef] [PubMed]

67. Zhang, C.; Lei, J.L.; Yu, P.; Xia, Y.Z.; Zhang, H.; Yang, L.; Kong, L.Y. Walsuronoid B induces mitochondrial and lysosomal dysfunction leading to apoptotic rather than autophagic cell death via ROS/p53 signaling pathways in liver cancer. Biochem. Pharmcol. 2017, 142, 71-86. [CrossRef]

68. Córdoba-Jover, B.; Arce-Cerezo, A.; Ribera, J.; Pauta, M.; Oró, D.; Casals, G.; Fernández-Varo, G.; Casals, E.; Puntes, V.; Jiménez, W.; et al. Cerium oxide nanoparticles improve liver regeneration after acetaminophen-induced liver injury and partial hepatectomy in rats. J. Nanobiotechnol. 2019, 17, 1-12. [CrossRef]

69. Jaiswal, A.K. Nrf2 signaling in coordinated activation of antioxidant gene expression. Free Radic. Biol. Med. 2004, 36, 1199-1207. [CrossRef] [PubMed]

70. Nguyen, T.; Sherratt, P.J.; Pickett, C.B. Regulatory Mechanisms Controlling Gene Expression Mediated by the Antioxidant Response Element. Annu. Rev. Pharmacol. Toxicol. 2003, 43, 233-260. [CrossRef] [PubMed]

71. Beyer, T.A.; Xu, W.; Teupser, D.; Auf Dem Keller, U.; Bugnon, P.; Hildt, E.; Thiery, J.; Kan, Y.W.; Werner, S. Impaired liver regeneration in Nrf2 knockout mice: Role of ROS-mediated insulin/IGF-1 resistance. EMBO J. 2008, 27, 212-223. [CrossRef]

72. Dayoub, R.; Vogel, A.; Schuett, J.; Lupke, M.; Spieker, S.M.; Kettern, N.; Hildt, E.; Melter, M.; Weiss, T.S. Nrf2 activates augmenter of liver regeneration (ALR) via antioxidant response element and links oxidative stress to liver regeneration. Mol. Med. 2013, 19, 237-244. [CrossRef] [PubMed]

73. Francés, D.E.; Ronco, M.T.; Ingaramo, P.I.; Monti, J.A.; Pisani, G.B.; Parody, J.P.; Pellegrino, J.M.; Carrillo, M.C.; Martin-Sanz, P.; Carnovale, C.E. Role of reactive oxygen species in the early stages of liver regeneration in streptozotocin-induced diabetic rats. Free Radic. Res. 2011, 45, 1143-1153. [CrossRef] [PubMed]

74. Scheidereit, C. Signal transduction: Docking IkB kinases. Nature 1998, 395, 225-226. [CrossRef]

75. European Association for the Study of the Liver (EASL); European Association for the Study of Diabetes (EASD); European Association for the Study of Obesity (EASO). EASL-EASD-EASO Clinical Practice Guidelines for the management of non-alcoholic fatty liver disease. J. Hepatol. 2016, 64, 1388-1402. [CrossRef] 
76. Chalasani, N.; Younossi, Z.; Lavine, J.E.; Charlton, M.; Cusi, K.; Rinella, M.; Harrison, S.A.; Brunt, E.M.; Sanyal, A.J. The diagnosis and management of nonalcoholic fatty liver disease: Practice guidance from the American Association for the Study of Liver Diseases. Hepatology 2018, 67, 328-357. [CrossRef] [PubMed]

77. Eslam, M.; Newsome, P.N.; Sarin, S.K.; Anstee, Q.M.; Targher, G.; Romero-Gomez, M.; Zelber-Sagi, S.; Wai-Sun Wong, V.; Dufour, J.F.; Schattenberg, J.M.; et al. A new definition for metabolic dysfunction-associated fatty liver disease: An international expert consensus statement. J. Hepatol. 2020, 73, 202-209. [CrossRef] [PubMed]

78. Younossi, Z.M.; Koenig, A.B.; Abdelatif, D.; Fazel, Y.; Henry, L.; Wymer, M. Global epidemiology of nonalcoholic fatty liver disease-Meta-analytic assessment of prevalence, incidence, and outcomes. Hepatology 2016, 64, 73-84.

79. Younossi, Z.; Anstee, Q.M.; Marietti, M.; Hardy, T.; Henry, L.; Eslam, M.; George, J.; Bugianesi, E. Global burden of NAFLD and NASH: Trends, predictions, risk factors and prevention. Nat. Rev. Gastroenterol. Hepatol. 2018, 15, 11-20.

80. Salomone, F.; Godos, J.; Zelber-Sagi, S. Natural antioxidants for non-alcoholic fatty liver disease: Molecular targets and clinical perspectives. Liver. Int. 2016, 36, 5-20. [CrossRef] [PubMed]

81. Shokrzadeh, M.; Abdi, H.; Asadollah-Pour, A.; Shaki, F. Nanoceria Attenuated High Glucose-Induced Oxidative Damage in HepG2 Cells. Cell J. 2016, 18, 97-102. [PubMed]

82. Hashem, R.M.; Rashd, L.A.; Hashem, K.S.; Soliman, H.M. Cerium oxide nanoparticles alleviate oxidative stress and decreases Nrf-2/HO-1 in D-GALN/LPS induced hepatotoxicity. Biomed. Pharm. 2015, 73, 80-86. [CrossRef]

83. Ibrahim, H.G.; Attia, N.; Hashem, F.E.Z.A.; El Heneidy, M.A.R. Cerium oxide nanoparticles: In pursuit of liver protection against doxorubicin-induced injury in rats. Biomed. Pharm. 2018, 10, 773-781. [CrossRef]

84. Carvajal, S.; Perramón, M.; Oró, D.; Casals, E.; Fernández-Varo, G.; Casals, G.; Parra, M.; González de la Presa, B.; Ribera, J.; Pastor, Ó; et al. Cerium oxide nanoparticles display antilipogenic effect in rats with non-alcoholic fatty liver disease. Sci. Rep. 2019, 9, 12848. [CrossRef] [PubMed]

85. Kobyliak, N.; Abenavoli, L.; Falalyeyeva, T.; Virchenko, O.; Natalia, B.; Beregova, T.; Bodnar, P.; Spivak, M. Prevention of NAFLD development in rats with obesity via the improvement of pro/antioxidant state by cerium dioxide nanoparticles. Clujul Med. 2016, 89, 229-235. [CrossRef] [PubMed]

86. Wasef, L.; Nassar, A.M.; El-Sayed, Y.S.; Samak, D.; Noreldin, A.; Elshony, N.; Saleh, H.; Elewa, Y.H.; Hassan, S.M.; Saati, A.A.; et al. The potential ameliorative impacts of cerium oxide nanoparticles against fipronil-induced hepatic steatosis. Sci. Rep. 2021, 1310. [CrossRef] [PubMed]

87. Kitchin, K.T.; Grulke, E.; Robinette, B.L.; Castellon, B.T. Metabolomic effects in HepG2 cells exposed to four TiO2 and two CeO2 nanomaterials. Environ. Sci. Nano 2014, 1, 466-477. [CrossRef]

88. Thai, S.F.; Wallace, K.A.; Jones, C.P.; Ren, H.; Castellon, B.T.; Crooks, J.; Grulke, E.A.; Kitchin, K.T. Differential Genomic Effects on Signaling Pathways by Two Different CeO2 Nanoparticles in HepG2 Cells. J. Nanosci. Nanotechnol. 2015, 15, 9925-9937. [CrossRef] [PubMed]

89. Kitchin, K.T.; Stirdivant, S.; Robinette, B.L.; Castellon, B.T.; Liang, X. Metabolomic effects of $\mathrm{CeO}_{2}, \mathrm{SiO}_{2}$ and $\mathrm{CuO}_{\text {metal oxide }}$ nanomaterials on HepG2 cells. Part. Fibre Toxicol. 2017, 14, 50. [CrossRef] [PubMed]

90. Parra-Robert, M.; Casals, E.; Massana, N.; Zeng, M.; Perramón, M.; Fernández-Varo, G.; Morales-Ruiz, M.; Puntes, V.; Jiménez, W.; Casals, G. Beyond the Scavenging of Reactive Oxygen Species (ROS): Direct Effect of Cerium Oxide Nanoparticles in Reducing Fatty Acids Content in an In Vitro Model of Hepatocellular Steatosis. Biomolecules 2019, 9, 425. [CrossRef] [PubMed]

91. Casals, E.; Gusta, M.F.; Piella, J.; Casals, G.; Jiménez, W.; Puntes, V. Intrinsic and Extrinsic Properties Affecting Innate Immune Responses to Nanoparticles: The Case of Cerium Oxide. Front. Immunol. 2017, 8, 970. [CrossRef]

92. Kobyliak, N.; Virchenko, O.; Falalyeyeva, T.; Kondro, M.; Beregova, T.; Bodnar, P.; Shcherbakov, O.; Bubnov, R.; Caprnda, M.; Delev, D.; et al. Cerium dioxide nanoparticles possess anti-inflammatory properties in the conditions of the obesity-associated NAFLD in rats. Biomed. Pharm. 2017, 90, 608-614. [CrossRef]

93. Rocca, A.; Moscato, S.; Ronca, F.; Nitti, S.; Mattoli, V.; Giorgi, M.; Ciofani, G. Pilot in vivo investigation of cerium oxide nanoparticles as a novel anti-obesity pharmaceutical formulation. Nanomedicine 2015, 11, 1725-1734. [CrossRef]

94. Parra-Robert, M.; Zeng, M.; Shu, Y.; Fernández-Varo, G.; Perramon, M.; Desai, D.; Chen, J.; Guo, D.; Zhang, X.; Morales-Ruiz, M.; et al. Mesoporous silica coated CeO2nanozymes with combined lipid-lowering and antioxidant activity induce long-term improvement of the metabolic profile in obese Zucker rats. Nanoscale 2021. [CrossRef]

95. Friedman, S.L.; Neuschwander-Tetri, B.A.; Rinella, M.; Sanyal, A.J. Mechanisms of NAFLD development and therapeutic strategies. Nat. Med. 2018, 24, 908-922. [CrossRef] [PubMed]

96. Sanyal, A.J.; Chalasani, N.; Kowdley, K.V.; McCullough, A.; Diehl, A.M.; Bass, N.M.; Neuschwander-Tetri, B.A.; Lavine, J.E.; Tonascia, J.; Unalp, A.; et al. Pioglitazone, vitamin E, or placebo for nonalcoholic steatohepatitis. N. Engl. J. Med. 2010, 362, 1675-1685. [CrossRef] [PubMed]

97. Del Campo, J.A.; Gallego, P.; Grande, L. Role of inflammatory response in liver diseases: Therapeutic strategies. World J. Hepatol. 2018, 10, 1-7. [CrossRef] [PubMed]

98. Parola, M.; Pinzani, M. Liver fibrosis: Pathophysiology, pathogenetic targets and clinical issues. Mol. Asp. Med. 2019, 65, 37-55. [CrossRef]

99. Lemasters, J.J.; Jaeschke, H. Oxidative Stress and Inflammation in the Live. In The Live; Arias, I.M., Alter, I.J., Boyer, J.L., Cohen, D.E., Shafritz, D.A., Thorgeirsson, S.S., Wolkoff, A.W., Eds.; Wiley Online Books: Hoboken, NJ, USA, 2020; pp. 714-727. [CrossRef] 
100. Mihm, S. Danger-Associated Molecular Patterns (DAMPs): Molecular Triggers for Sterile Inflammation in the Liver. Int. J. Mol. Sci. 2018, 19, 3104. [CrossRef]

101. Greenhalgh, S.N.; Thompson, A.I.; Henderson, N.C.; Iredale, J.P. Oxidative Stress and Liver Inflammation. In Studies on Hepatic Disorders; Albano, E., Parola, M., Eds.; Springer: Berlin/Heidelberg, Germany, 2015; pp. 123-147. [CrossRef]

102. Brenner, C.; Galluzzi, L.; Kepp, O.; Kroemer, G. Decoding cell death signals in liver inflammation. J. Hepatol. 2013, 59, 583-594. [CrossRef] [PubMed]

103. Xu, D.; Xu, M.; Jeong, S.; Qian, Y.; Wu, H.; Xia, Q.; Kong, X. The Role of Nrf2 in Liver Disease: Novel Molecular Mechanisms and Therapeutic Approaches. Front. Pharmacol. 2018, 9, 1428. [CrossRef] [PubMed]

104. Shin, S.M.; Yang, J.H.; Ki, S.H. Role of the Nrf2-ARE Pathway in Liver Diseases. Oxid. Med. Cell Longev. 2013, $2013,763257$. [CrossRef]

105. Bataller, R.; Brenner, D. Liver fibrosis. J. Clin. Investig. 2005, 115, 209-218. [CrossRef]

106. Sadidi, H.; Hooshmand, S.; Ahmadabadi, A.; Javad, H.S.; Baino, F.; Vatanpour, M.; Kargozar, S. Cerium Oxide Nanoparticles (Nanoceria): Hopes in Soft Tissue Engineering. Molecules 2020, 25, 4559.

107. Ribera, J.; Rodríguez-Vita, J.; Cordoba, B.; Portolés, I.; Casals, G.; Casals, E.; Jiménez, W.; Puntes, V.; Morales-Ruiz, M. Functionalized cerium oxide nanoparticles mitigate the oxidative stress and pro-inflammatory activity associated to the portal vein endothelium of cirrhotic rats. PLoS ONE 2019, 14, e0218716. [CrossRef]

108. Carvajal, S.; Perramón, M.; Casals, G.; Oró, D.; Ribera, J.; Morales-Ruiz, M.; Casals, E.; Casado, P.; Melgar-Lesmes, P.; FernándezVaro, G.; et al. Cerium Oxide Nanoparticles Protect against Oxidant Injury and Interfere with Oxidative Mediated Kinase Signaling in Human-Derived Hepatocytes. Int. J. Mol. Sci. 2019, 20, 5959. [CrossRef] [PubMed]

109. Eilenberger, C.; Selinger, F.; Rothbauer, M.; Lin, Y.; Limbeck, A.; Schädl, B.; Grillari, J.; Kavok, N.S.; Klochkov, V.K.; Malyukin, Y.V.; et al. Cytotoxicity, Retention, and Anti-inflammatory Effects of a $\mathrm{CeO}_{2}$ Nanoparticle-Based Supramolecular Complex in a 3D Liver Cell Culture Mode. ACS Pharmacol. Transl. Sci. 2020, 4, 101-106. [CrossRef] [PubMed]

110. Adebayo, O.A.; Akinloye, O.; Adaramoye, O.A. Cerium Oxide Nanoparticles Attenuate Oxidative Stress and Inflammation in the Liver of Diethylnitrosamine-Treated Mice. Biol. Trace. Elem. Res. 2020, 193, 214-225. [CrossRef] [PubMed]

111. Fernández-Varo, G.; Perramón, M.; Carvajal, S.; Oró, D.; Casals, E.; Boix, L.; Oller, L.; Macías-Muñoz, L.; Marfà, S.; Casals, G.; et al. Bespoken Nanoceria: An Effective Treatment in Experimental Hepatocellular Carcinoma. Hepatology 2020, 72, 1267-1282. [CrossRef] [PubMed]

112. Cowled, P.; Fitridge, R. Pathophysiology of Reperfusion Injury. In Mechanisms of Vascular Disease: A Reference Book for Vascular Specialists; Fitridge, R., Thompson, M., Eds.; University of Adelaide Press: Adelaide, Australia, 2011; pp. 331-345. Available online: https: / www.ncbi.nlm.nih.gov/books/NBK534267/ (accessed on 21 April 2021).

113. Manne, N.D.P.K.; Arvapalli, R.; Graffeo, V.A.; Bandarupalli, V.V.K.; Shokuhfar, T.; Patel, S.; Rice, K.M.; Ginjupalli, G.K.; Blough, E.R. Prophylactic Treatment with Cerium Oxide Nanoparticles Attenuate Hepatic Ischemia Reperfusion Injury in Sprague Dawley Rats. Cell Physiol. Biochem. 2017, 42, 1837-1846. [CrossRef] [PubMed]

114. Yan, J.; Li, S.; Li, S. The role of the liver in sepsis. Int. Rev. Immunol. 2014, 33, 498-510. [CrossRef]

115. Selvaraj, V.; Nepal, N.; Rogers, S.; Manne, N.D.P.K.; Arvapalli, R.; Rice, K.M.; Asano, S.; Fankhanel, E.; Ma, J.J.; Shokuhfar, T.; et al. Inhibition of MAP kinase/NF-kB mediated signaling and attenuation of lipopolysaccharide induced severe sepsis by cerium oxide nanoparticles. Biomaterials 2015, 59, 160-171. [CrossRef]

116. Siegel, R.L.; Miller, K.D.; Jemal, A. Cancer Statistics. CA Cancer J. Clin. 2018, 68, 7-30. [CrossRef]

117. Bray, F.; Ferlay, J.; Soerjomataram, I.; Siegel, R.L.; Torre, L.A.; Jemal, A. Global cancer statistics 2018: GLOBOCAN estimates of incidence and mortality worldwide for 36 cancers in 185 countries. CA Cancer J. Clin. 2018, 68, 394-424. [CrossRef]

118. European Association for the Study of the Liver; European Organisation for Research and Treatment of Cancer. EASL-EORTC clinical practice guidelines: Management of hepatocellular carcinoma. Hepatology 2012, 56, 908-943. [CrossRef]

119. Yang, Y.M.; Kim, S.Y.; Seki, E. Inflammation and Liver Cancer: Molecular Mechanisms and Therapeutic Targets. Semin. Liver Dis. 2019, 39, 26-42. [CrossRef]

120. Michelotti, G.A.; Machado, M.V.; Diehl, A.M. NAFLD, NASH and liver cancer. Nat. Rev. Gastroenterol. Hepatol. 2013, 10, 656-665. [CrossRef] [PubMed]

121. Maeda, S.; Kamata, H.; Luo, J.L.; Leffert, H.; Karin, M. IKKbeta couples hepatocyte death to cytokine-driven compensatory proliferation that promotes chemical hepatocarcinogenesis. Cell 2005, 121, 977-990. [CrossRef]

122. Calvisi, D.F. Activation of the canonical Wnt/beta-catenin pathway confers growth advantages in c-Myc/E2F1 transgenic mouse model of liver cancer. J. Hepatol. 2005, 42, 842-849. [CrossRef] [PubMed]

123. Ringelhan, M.; Pfister, D.; O'Connor, T.; Pikarsky, E.; Heikenwalder, M. The immunology of hepatocellular carcinoma. Nat. Immunol. 2018, 19, 222-232. [CrossRef] [PubMed]

124. Chang, L.; Wang, Y.; Zhang, J.; Guo, T. The best strategy for HCC patients at each BCLC stage. A network meta-analysis of observational studies. Oncotarget 2017, 8, 20418-20427. [CrossRef] [PubMed]

125. Bruix, J.; Reig, M.; Sherman, M. Evidence-based diagnosis, staging, and treatment of patients with hepatocellular carcinoma. Gastroenterology 2016, 150, 835-853. [CrossRef] [PubMed]

126. Llovet, J.M.; Ricci, S.; Mazzaferro, V.; Hilgard, P.; Gane, E.; Blanc, J.F.; de Oliveira, A.C.; Santoro, A.; Raoul, J.L.; Forner, A.; et al. Sorafenib in advanced hepatocellular carcinoma. N. Engl. J. Med. 2008, 359, 378-390. [CrossRef] [PubMed] 
127. Bruix, J.; Qin, S.; Merle, P.; Granito, A.; Huang, Y.H.; Bodoky, G.; Pracht, M.; Yokosuka, O.; Rosmorduc, O.; Breder, V.; et al. RESORCE Investigators. Regorafenib for patients with hepatocellular carcinoma who progressed on sorafenib treatment (RESORCE): A randomised, double-Blind, placebo-Controlled, phase 3 trial. Lancet 2017, 389, 56-66. [CrossRef]

128. Forner, A.; Reig, M.; Bruix, J. Hepatocellular Carcinoma. Lancet 2018, 391, 1301-1314. [CrossRef]

129. Wang, N.; Feng, Y.; Zhu, M.; Tsang, C.M.; Man, K.; Tong, Y.; Tsao, S.W. Berberine induces autophagic cell death and mitochondrial apoptosis in liver cancer cells: The cellular mechanism. J. Cell Biochem. 2010, 111, 1426-1436. [CrossRef]

130. Xu, W.W.; Li, B.; Lai, E.T.; Chen, L.; Huang, J.J.; Cheung, A.L.; Cheung, P.C. Water extract from Pleurotus pulmonarius with antioxidant activity exerts in vivo chemoprophylaxis and chemosensitization for liver cancer. Nutr. Cancer 2014, 66, 989-998. [CrossRef] [PubMed]

131. Murphy, E.A.; Majeti, B.K.; Barnes, L.A.; Makale, M.; Weis, S.M.; Lutu-Fuga, K.; Wrasidlo, W.; Cheresh, D.A. Nanoparticlemediated drug delivery to tumor vasculature suppresses metastasis. Proc. Natl. Acad. Sci. USA 2008, 105, 9343-9348. [CrossRef]

132. Wason, M.S.; Zhao, J. Cerium oxide nanoparticles: Potential applications for cancer and other diseases. Am. J. Transl. Res. 2013, 5, 126-131. [PubMed]

133. Xu, X. Cancer nanomedicine: From targeted delivery to combination therapy. Trends Mol. Med. 2015, 21, 223-232. [CrossRef] [PubMed]

134. Chauhan, V.P.; Jain, R.K. Strategies for advancing cancer nanomedicine. Nat. Mater. 2013, 12, 958-962. [CrossRef] [PubMed]

135. Dowding, J.M.; Das, S.; Kumar, A.; Dosani, T.; McCormack, R.; Gupta, A.; Sayle, T.X.; Sayle, D.C.; von Kalm, L.; Seal, S.; et al. Cellular interaction and toxicity depend on physicochemical properties and surface modification of redox-active nanomaterials. ACS Nano 2013, 7, 4855-4868.

136. Li, Z.; Wu, X.; Li, J.; Yao, L.; Sun, L.; Shi, Y.; Zhang, W.; Lin, J.; Liang, D.; Li, Y. Antitumor activity of celastrol nanoparticles in a xenograft retinoblastoma tumor model. Int. J. Nanomed. 2012, 7, 2389. [CrossRef]

137. Chen, F.; Zhang, X.H.; Hu, X.D.; Zhang, W.; Lou, Z.C.; Xie, L.H.; Liu, P.D.; Zhang, H.Q. Enhancement of radiotherapy by ceria nanoparticles modified with neogambogic acid in breast cancer cells. Int. J. Nanomed. 2015, 10, 4957. [CrossRef] [PubMed]

138. Cai, X.; Seal, S.; McGinnis, J.F. Sustained inhibition of neovascularization in vldlr $-/-$ mice following intravitreal injection of cerium oxide nanoparticles and the role of the ASK1-P38/JNK-NF-KB pathway. Biomaterials 2014, 35, 249-258. [CrossRef]

139. Eom, H.J.; Choi, J. Oxidative stress of $\mathrm{CeO} 2$ nanoparticles via p38-Nrf-2 signaling pathway in human bronchial epithelial cell, Beas-2B. Toxicol. Lett. 2009, 187, 77-83. [CrossRef] [PubMed]

140. Otsuka, H. PEGylated nanoparticles for biological and pharmaceutical applications. Adv. Drug Deliv. Rev. 2003, 55, 403-419. [CrossRef]

141. Yang, Z.Y.; Luo, S.L.; Li, H.; Dong, S.W.; He, J.; Jiang, H.; Li, R.; Yang, X.C. Alendronate as a robust anchor for ceria nanoparticle surface coating: Facile binding and improved biological properties. RSC Adv. 2014, 4, 59965-59969. [CrossRef] 